Staff Working Paper/Document de travail du personnel 2017-42

\title{
Policy Rules for Capital Controls
}

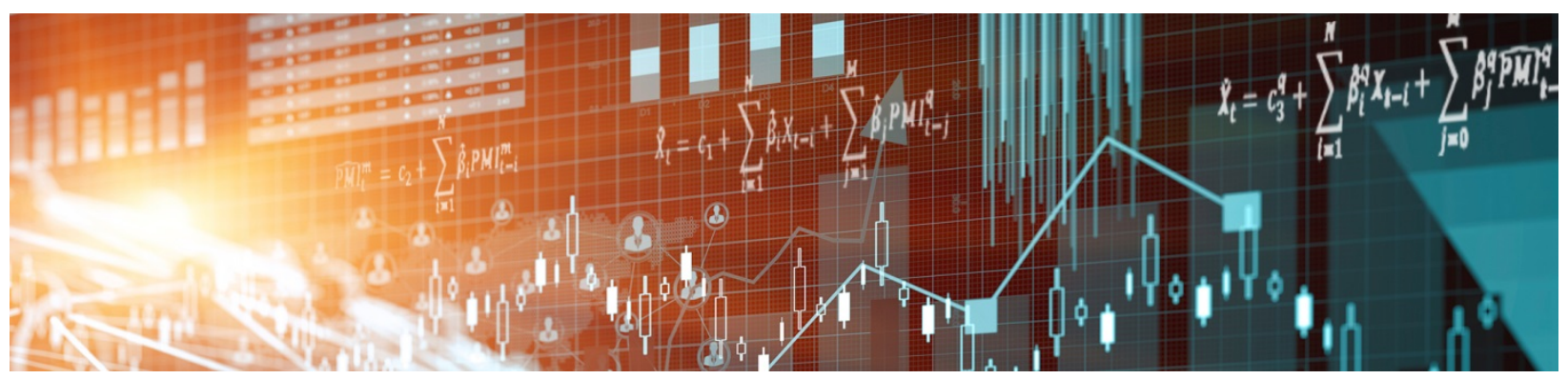

\section{by Gurnain Pasricha}


Bank of Canada Staff Working Paper 2017-42

October 2017

\title{
Policy Rules for Capital Controls
}

by

\author{
Gurnain Pasricha \\ International Economic Analysis Department \\ Bank of Canada \\ Ottawa, Ontario, Canada K1A 0G9 \\ gpasricha@bankofcanada.ca
}




\section{Acknowledgements}

The work for this paper was supported by the Visiting Central Bank Research Fellowship of the BIS. The views expressed in this paper are mine and do not necessarily reflect those of the Bank of Canada or the BIS. My thanks to Joshua Aizenman, Eric Bannem, Martin Bijsterbosch, Anusha Chari, Patrick Conway, Andres Fernandez, Meredith Fraser-Ohman, Leonardo Gambacorta, Philipp Hartmann, Anton Korinek, Ann Louise Mahoney, Robert McCauley, Aaron Mehrotra, Nikhil Patel, Vikram Rai, Ricardo Sousa, conference participants at Canadian Economic Association Meetings 2017, and seminar participants at the Bank of Canada, Bank for International Settlements, European Central Bank and UNC Chapel Hill and an anonymous referee for helpful comments and suggestions. I also thank Min Jae (Arthur) Kim for excellent research support. 


\section{Abstract}

This paper attempts to borrow the tradition of estimating policy reaction functions in monetary policy literature and apply it to capital controls policy literature. Using a novel weekly dataset on capital controls policy actions in 21 emerging economies over the period 1 January 2001 to 31 December 2015, I examine the mercantilist and macroprudential motivations for capital control policies. I introduce a new proxy for mercantilist motivations: the weighted appreciation of an emerging-market currency against its top five trade competitors. There is clear evidence that past emerging-market policy systematically responds to both mercantilist and macroprudential motivations. The choice of instruments is also systematic: policy-makers respond to mercantilist concerns by using both instruments - inflow tightening and outflow easing. They use only inflow tightening in response to macroprudential concerns. I also find that policy is acyclical to foreign debt but is countercyclical to domestic bank credit to the private non-financial sector. The adoption of explicit financial stability mandates by central banks or the creation of inter-agency financial stability councils increased the weight of macroprudential factors in the use of capital controls policies. Countries with higher exchange rate pass-through to export prices are more responsive to mercantilist concerns.

Bank topics: International topics; Financial system regulation and policies; Financial stability; Exchange rate regimes

JEL codes: F3, F4, F5, GO, G1

\section{Résumé}

Cette étude tente de contribuer à la littérature sur les mesures de contrôle des capitaux en s'inspirant des travaux consacrés à l'estimation de la fonction de réaction des politiques monétaires. À partir d'une nouvelle base de données hebdomadaires sur les mesures de contrôle des capitaux prises par 21 économies émergentes entre le $1^{\text {er }}$ janvier 2001 et le 31 décembre 2015 , nous analysons les motifs - mercantilistes ou prudentiels - derrière le recours aux politiques de contrôle des capitaux. Nous proposons une nouvelle mesure indirecte des motifs mercantilistes : I'appréciation pondérée de la monnaie de l'économie émergente vis-à-vis de celle de ses cinq premiers concurrents commerciaux. II ressort clairement de l'analyse que les mesures de contrôle des capitaux dans les économies émergentes ont, dans le passé, été systématiquement adoptées pour des motifs mercantilistes et macroprudentiels. Le choix des instruments mis en œuvre est lui aussi systématique: les décideurs ont recours à la fois à des mesures de restriction des entrées de capitaux et à l'assouplissement des contrôles sur les 
capitaux sortants lorsqu'ils sont animés par des motifs macroprudentiels. En revanche, ils utilisent uniquement les restrictions des entrées de capitaux quand leurs décisions sont motivées par des préoccupations macroprudentielles. Nous montrons également que les mesures de contrôle ont un caractère acyclique pour la dette extérieure, mais des effets contra-cycliques à l'égard du crédit bancaire au secteur privé non financier. L'intégration d'un objectif explicite de stabilité financière dans le mandat des banques centrales, ou la création de structures interinstitutionnelles en faveur de la stabilité financière, accroît le poids des considérations macroprudentielles dans l'adoption de mesures de contrôle des capitaux. Ces mesures sont plus sensibles aux préoccupations mercantilistes dans les pays où le degré de transmission des variations du taux de change aux prix à l'exportation est plus élevé.

Sujets: Questions internationales; Réglementation et politiques relatives au système financier; Stabilité financière; Régimes de taux de change

Codes JEL : F3, F4, F5, G0, G1 


\section{Non-Technical Summary}

Are capital controls macroprudential or mercantilist? This question is of great importance in the ongoing reshaping of the global financial architecture, but there is surprisingly little empirical evidence on how these tools have actually been used by emerging markets. The paper asks with which objectives - macroprudential or mercantilist - have policy-makers in emerging economies used capital controls. It takes a policy reaction function approach, clearly delineating the different motivations, and the trade-offs therein. The paper uses a detailed weekly dataset on capital controls policy that directly measures policy actions by 21 major emerging-market economies (EMEs) over the period 2001-2015. It also proposes a novel proxy for mercantilist concerns to disentangle them from macroprudential concerns. This proxy measures the real appreciation of an EME's currency against its top five trade competitors.

The idea of asking how policy should or does react to competing objectives is not new in economics, although it is new in the capital controls literature. Monetary economics has a long tradition of estimating monetary policy rules (e.g., Taylor, 1993). The premise is that well-designed policy rules can allow policy-makers to overcome time-inconsistency problems with monetary policy. In a similar vein, policy rules for capital controls could constrain the ability to expropriate past investments. This paper estimates a descriptive reaction function, without claiming that such reaction functions reflect optimal rules. Even without an assessment of optimality, this exercise is important as it contributes to improving the transparency of policy.

The results provide clear evidence that capital controls policy in emerging markets has been systematic, and that it has responded to both macroprudential and mercantilist motivations. The use of net inflow tightening measures can be described by a function of mercantilist and macroprudential motivations. The results also suggest that capital controls have not systematically been targeted to foreign or foreign currency debt. Rather, policy appears that inflow controls are countercyclical to domestic bank credit to the private nonfinancial sector. The tightening of controls on foreign credit when domestic credit is booming may simply reflect that regulators find it easier to target foreign credit rather than domestic credit, either because of lack of adequate domestic prudential tools or because of shortcomings of domestic institutional frameworks. As capital controls become more widely used as tools of macroprudential policies, future research and policy discussions could focus on how best to ensure that these instruments are directly targeted to the vulnerabilities they seek to address. Exploring the two motivations further, I find development in governance arrangements for macroprudential policies led to capital controls policies responding more to systemic risk concerns. I also find that mercantilism has a basis in higher exchange rate passthrough to export prices. 


\section{Introduction}

Capital controls are restrictions on cross-border trade in assets. The recent global financial crisis has reignited the debate on the systematic use of capital controls to manage the domestic economic and financial cycles. A new policy paradigm has emerged, which views capital controls as having a preventive role in maintaining financial stability, i.e., as ex-ante tools to prevent buildup of systemic risk by limiting the growth of credit (BIS-FSB-IMF, 2011; G20, 2011; Ostry et al., 2011; Ostry et al., 2012).

The new paradigm is backed by a growing theoretical literature that views capital controls as optimal ex-ante policies in the presence of pecuniary externalities in residents' borrowing decisions (Mendoza, 2002; Korinek, 2010; Korinek and Sandri, 2016; Bianchi, 2011; Uribe, 2007). In this framework, residents face a collateral constraint that depends on the real exchange rate. Individual agents take the real exchange rate (and the value of the collateral) as given when taking their borrowing decisions, but in aggregate, the real exchange rate depends on the borrowing decisions of the individuals. This feedback loop leads to excessive foreign borrowing in good times, and increases the probability of a crisis. Ex-ante capital controls that limit real exchange rate appreciation in cyclical upturns also limit excessive borrowing, and are therefore viewed as macroprudential tools in this literature.

While much of the recent literature focuses on the macroprudential objective of capital controls policy, there is another potential objective of capital controls policy - the mercantilist objective. ${ }^{1}$ The mercantilist objective is to promote exports by manipulating the terms of trade or preventing foreign control of strategic industries (Bernanke, 2015; Costinot et al., 2014; Heathcote and Perri, 2016; Dooley et al., 2014). Proponents of this view argue that attempts to prevent the exchange rate from appreciating - either through capital controls or reserves accumulation - are in fact motivated by the objective of gaining trade advantage over export competitors. Further, they argue that imposition of capital controls by one emerging-market economy (EME) during upturns in the global financial cycle only deflects these flows to other emerging markets and can lead to a beggar-thy-neighbour currency war. ${ }^{2}$

Are capital controls macroprudential or mercantilist? This question is of great importance in the ongoing reshaping of the global financial architecture, but there is surprisingly little empirical evidence on how these tools have actually been used by emerging markets. A recent paper by Fernández et al. (2015b) finds that capital controls do not vary over

\footnotetext{
${ }^{1}$ The term "new mercantilism" was used in the context of the reserves accumulation debate before the global financial crisis, in the paper by Dooley et al. (2003), and has since been used to describe the strategy of managing the exchange rate through systematic calibration of capital controls on inflows as well. For empirical literature assessing mercantilist motive in reserves accumulation, see Aizenman and Lee (2007), Ghosh et al. (2012) and references therein.

${ }^{2}$ For evidence on the spillover effects of capital controls, see Pasricha et al. (2015), Forbes et al. (2016) and references therein.
} 
the business cycle. On the mercantilism objective, there is only indirect evidence that certain types of inflow controls benefit the largest exporting firms (Alfaro et al., 2014).

An unexplored issue underlying the macroprudential basis for capital controls is that it assumes that policy-makers face a binary choice - capital controls are either macroprudential or mercantilist, and at most times the two objectives require the same policy response. That is, much of the debate assumes that the exchange rate cycle and the financial cycle in emerging economies are highly synchronized. However, recent data suggest otherwise. Table 1 shows the correlations between real effective exchange rate (REER) and external credit gap for 19 emerging economies, for 2001Q1-2015Q4 and its various subperiods. The recent models for macroprudential capital controls assume that this correlation is positive, i.e., REER appreciates when external credit is booming. However, the table shows that this correlation was positive only for eight economies for the period 2001Q1-2015Q4. For 13 countries, the correlation was positive in at least one sub-period, but for 6 countries, it was always negative. This table suggests that the two objectives of capital controls policy may involve trade-offs. When the exchange rate is appreciating but the credit-to-gross-domesticproduct (GDP) gap is low, tighter capital inflow controls could further reduce credit availability in the domestic economy and curtail economic growth. On the other hand, looser inflow controls to boost domestic credit could lead to a further appreciation of the currency and hurt exporting and import-competing sectors. How have policy-makers responded in such situations?

The paper asks: With which objectives - macroprudential or mercantilist - have policy-makers in emerging economies used capital controls? It takes a policy reaction function approach, clearly delineating the different motivations, and the trade-offs therein. There is some recent literature that has tried to predict capital controls policies (Fernández et al., 2015b; Fratzscher, 2014; Forbes et al., 2015; Aizenman and Pasricha, 2013). However, these papers focus on specific variables to which policy responds, not on the motivation that these variables represent. For example, the aforementioned papers assess whether policy reacts to net capital inflows (NKI) and find that it does. But the motivation behind that NKI response could be macroprudential or mercantilist. This paper estimates a descriptive, empirical policy reaction function to explore how policy reacts to competing objectives.

The idea of asking how policy should or does react to competing objectives is not new in economics, although it is new in the capital controls literature. Monetary economics has a long tradition of estimating monetary policy rules (e.g., Taylor, 1993). The premise is that well-designed policy rules can allow policy-makers to overcome time-inconsistency problems with monetary policy, gain credibility and therefore make policy more effective. Policy rules can also allow policy-makers to communicate policy more effectively, and enhance accountability of the monetary authority. In a similar vein, transparency around the use of capital controls policy can help attract capital inflows and prevent destabilizing outflows when the controls are actually used, by constraining the ability to expropriate past investments 
(Ljungqvist and Sargent, 2004). ${ }^{3}$ It can also strengthen the accountability of the macroprudential authority and assuage concerns about the spillovers of such policy. The Taylor rule is prescriptive - it recommends how policy-makers should react. ${ }^{4}$ This paper, by contrast, estimates a descriptive reaction function, without claiming that such reaction functions reflect optimal rules. ${ }^{5}$ Even without an assessment of optimality, this exercise is important as it contributes to improving the transparency of policy.

Table 1: Correlation between real effective exchange rate and external credit gap

\begin{tabular}{|c|c|c|c|c|}
\hline & $\begin{array}{l}\text { 2001Q1- } \\
2015 Q 4\end{array}$ & $\begin{array}{l}\text { 2001Q1- } \\
2005 Q 4\end{array}$ & $\begin{array}{l}\text { 2006Q1- } \\
2010 Q 4\end{array}$ & $\begin{array}{l}\text { 2011Q1- } \\
\text { 2015Q4 }\end{array}$ \\
\hline$A R G$ & $0.40 * *$ & -0.30 & $0.61 * *$ & -0.21 \\
\hline BRA & $-0.62 * * *$ & $-0.89 * * *$ & $0.46^{*}$ & $-0.93 * * *$ \\
\hline $\mathrm{CHL}$ & $-0.68 * * *$ & $-0.85 * * *$ & $0.57 * *$ & $-0.89 * * *$ \\
\hline $\mathrm{CHN}$ & $0.71 * * *$ & -0.44 & 0.34 & $0.60 * *$ \\
\hline $\mathrm{COL}$ & $-0.52 * * *$ & -0.34 & $-0.48^{*}$ & $-0.91 * * *$ \\
\hline CZE & $0.63^{* * *}$ & 0.39 & $0.81 * * *$ & 0.19 \\
\hline HUN & $0.59 * * *$ & $0.55^{*}$ & 0.08 & $0.87^{* * *}$ \\
\hline IDN & $0.75 * * *$ & $-0.71 * * *$ & $0.85^{* * *}$ & 0.32 \\
\hline IND & -0.18 & -0.24 & -0.43 & -0.04 \\
\hline KOR & $-0.80 * * *$ & $-0.73 * * *$ & $-0.96 * * *$ & $-0.91 * * *$ \\
\hline MEX & $-0.73 * * *$ & $0.51^{*}$ & $-0.84^{* * *}$ & -0.41 \\
\hline MYS & $-0.49 * * *$ & $0.63^{* *}$ & $-0.51 *$ & $-0.80 * * *$ \\
\hline PER & $0.50 * * *$ & $0.80 * * *$ & $0.71 * * *$ & $0.55^{*}$ \\
\hline PHL & $-0.42 * * *$ & -0.32 & 0.35 & $-0.58 * *$ \\
\hline POL & 0.20 & $-0.47^{*}$ & -0.40 & $0.57^{* *}$ \\
\hline RUS & $-0.44 * * *$ & $-0.92 * * *$ & -0.36 & $-0.66 * *$ \\
\hline THA & $0.89 * * *$ & $-0.70 * * *$ & $0.65^{* *}$ & $0.51^{*}$ \\
\hline TUR & $-0.46 * * *$ & $-0.79 * * *$ & -0.33 & $-0.54 *$ \\
\hline ZAF & $-0.88 * * *$ & $-0.92 * * *$ & $-0.75 * * *$ & $-0.92 * * *$ \\
\hline $\mathrm{N}$ & 60 & 20 & 20 & 20 \\
\hline
\end{tabular}

Note: Country abbreviations are ISO codes. Real effective exchange rate is the JP Morgan broad index, with 2010=100. Increases in REER imply appreciation of the currency. External credit gap is the deviation of external credit from its lagged 10year moving average. External credit is the sum of stock of liabilities to BIS reporting banks (locational banking statistics) and the outstanding stock of international debt securities (from BIS International Debt Securities Database). ${ }^{* * *} p<0.01,{ }^{* *} p<0.05$, * $p<0.10$

${ }^{3}$ In Chapter 15, Ljungqvist and Sargent (2004) show that under discretion, the government has an incentive to tax all past investment at time 0 and then set the capital tax to zero for future dates. The reaction to India's capital controls during the taper tantrum episode suggests that the expropriation concerns continue to be important. On August 14, 2013, in an attempt to reduce net capital outflows, India tightened controls on foreign investment by Indian residents. This policy change was interpreted by foreign investors as a potential precursor to restrictions on withdrawals of existing foreign investments in the country, and may have exacerbated the depreciation pressures on the rupee (Basu et al., 2014).

${ }^{4}$ However, when he proposed it in 1993, one of Taylor's contributions was to show that his rule was also descriptive that the optimal rule that theory predicted turned out also to describe well the behavior of the Federal Reserve Board in the 1980 s and early ' 90 s.

${ }^{5}$ An assessment of whether these reaction functions were optimal would have to come from theory or from an evaluation of outcomes achieved during this period. 
A related contribution of the paper is that it introduces a novel proxy for mercantilist concerns, to disentangle them from macroprudential concerns. Both the nominal exchange rate against major currencies (US dollar or euro) and the real effective exchange rate suffer from the shortcoming that they could reflect both macroprudential and mercantilist motivations (as most EME agents are able to borrow only in hard currencies of countries that are also main export destinations and import suppliers for these EMEs). EMEs' use of capital controls to prevent REER appreciation or appreciation against the US dollar could reflect the desire to prevent an increase in collateral value (as envisaged in recent literature) or the desire to promote exports or protect import-competing industries. Therefore, I propose a novel proxy for mercantilist concerns that measures the real appreciation of an EME's currency against its top five trade competitors. As these competitors are emerging or developing countries, in whose currencies the EMEs do not borrow, the movements of the EME currencies against the currencies of these countries does not reflect macroprudential concerns, but captures only mercantilist concerns. I survey the recent theoretical literature to clearly define other testable hypotheses with respect to different motivations for using capital controls. This allows me to identify mutually exclusive sets of macrofinancial variables to define macroprudential and mercantilist motivations.

A third contribution of the paper is that it uses a detailed weekly dataset on capital controls policy that directly measures policy actions by 21 major emerging market economies over the period 2001w1-2015w52. I extend the Pasricha et al. (2015) dataset for four years, 2011-2015, and use the announcement dates of the policy actions, rather than the effective dates used in Pasricha et al. (2015). The use of data on policy actions also closely parallels the monetary literature on modeling central bank policy rate. Two recent papers that assess the motivations for inflow controls — Fratzscher (2014) and Fernández et al. (2015b) - use annual datasets that are better measures of cross-country variation in existence of capital controls on different types of transactions than of actual policy changes. ${ }^{6}$

Finally, this paper is the first to provide evidence that strengthening the institutional frameworks for macroprudential policy increases the weight of macroprudential motivations even in the use of capital controls policy in emerging markets. In recent years, a number of emerging markets have strengthened their governance frameworks by adopting explicit financial stability mandates by central banks or the creation of inter-agency financial stability councils (Table 2). If these developments led to capital controls policies responding more to systemic risk concerns, even though capital controls are often not solely under the purview of

\footnotetext{
${ }^{6}$ Forbes et al. (2015) and Aizenman and Pasricha (2013) also use datasets on capital control policy actions. However, the Forbes study uses data only for the post-global financial crisis period, from 2009-2011, and the focus of the paper is on estimating effects of capital controls rather than on disentangling the different motivations for using capital controls. Aizenman and Pasricha (2013) focus on outflow controls only, and on whether the possible loss of fiscal revenue from repression constrained EMEs' use of outflow controls to manage the net capital inflow pressures.
} 
a single authority, this strengthens the case for the recent international efforts to develop governance arrangements for macroprudential policies.

The paper has a number of new and interesting results on the use of capital controls in emerging markets. The results provide evidence that capital controls policy in emerging economies has been systematic, and that it has responded to both macroprudential and mercantilist motivations. The use of net inflow tightening measures can be described by a function of mercantilist and macroprudential motivations. Moreover, I find that the choice of instruments is systematic: policy-makers respond to mercantilist concerns by using both instruments - inflow tightening and outflow easing. However, they use only inflow tightening in response to macroprudential concerns. This is the first paper to provide evidence of the existence of a macroprudential motivation in the use of capital controls policy, even before these controls were generally acknowledged as valid tools of the macroprudential policy toolkit. Yet, the results in this paper also underline that the concerns about a currency war are also justified - capital controls have also been systematically used to preserve competitive advantage in trade.

Further, I find that policy is not countercyclical to the specific macroprudential concerns related to external or foreign currency borrowing. Rather, policy appears acyclical to these variables, but is countercyclical to domestic bank credit to the private non-financial sector. This choice seems rational - EMEs prevent domestic residents from borrowing abroad by tightening inflow controls when domestic banks are lending at a brisk pace, but ease restrictions on foreign borrowing when the domestic bank credit-to-GDP gap is low (for example, if domestic banks are saddled with non-performing loans [NPLs], as in the post-2012 world). The targeting of foreign credit when domestic credit is booming may reflect the possibility that regulators find it easier to target foreign credit rather than domestic credit, either because of a lack of adequate domestic prudential tools, or because of shortcomings in domestic institutional frameworks. For example, if domestic regulators can do little to stem excessive lending to politically preferred sectors in economies where state banks dominate domestic lending, they may prefer to change restrictions on foreign credit to manage total credit in the economy. Exploring the two motivations further, I find development in governance arrangements for macroprudential policies led to capital controls policies responding more to systemic risk concerns. I also find that mercantilism has basis in higher exchange rate pass-through (ERPT) to export prices. Higher ERPT to export prices means that exporters do not change the prices in their domestic currency much in response to appreciation of their currency. As a result, the customers of these countries face much of the cost of the currency appreciation, potentially making the exports of these countries more sensitive to appreciation. I find that countries with high export price ERPT react more strongly to mercantilist motivations, particularly when the exchange rate pressures against competitors are strong. 
Table 2: Key developments in macroprudential policy frameworks in emerging markets after 2008

\begin{tabular}{|c|c|}
\hline Country & $\begin{array}{l}\text { Main developments in frameworks to monitor systemic risk and } \\
\text { coordinate financial policy among regulators }\end{array}$ \\
\hline Brazil & $\begin{array}{l}\text { A sub-committee to monitor the stability of the national financial system (SUMEF) was } \\
\text { established in 2010. Banco Central do Brasil established an internal Financial Stability } \\
\text { Committee (COMEF) in May } 2011 .\end{array}$ \\
\hline Chile & $\begin{array}{l}\text { Financial Stability Council (CEF), a council of regulators, was established by presidential } \\
\text { decree in } 2011 \text { as an advisory body. It was formalized in } 2014 \text { by law. }\end{array}$ \\
\hline China & $\begin{array}{l}\text { Financial Crisis Response Group (FCRG), a council of regulators, was first convened in } 2008 \\
\text { and formally established in August } 2013 .\end{array}$ \\
\hline India & $\begin{array}{l}\text { Financial Stability and Development Council was established in December } 2010 \text {, as a council } \\
\text { of regulators chaired by the finance minister, to oversee macroprudential regulation and } \\
\text { facilitate regulatory cooperation. }\end{array}$ \\
\hline Indonesia & $\begin{array}{l}\text { Bank Indonesia (BI) was given the mandate to exercise macroprudential supervision by Act } \\
\text { No. } 21 \text { of } 2011 \text { concerning the Financial Services Authority (OJK). }\end{array}$ \\
\hline Korea & $\begin{array}{l}\text { Macroeconomic financial Meeting (MEM), a deputy-level council of regulators meeting } \\
\text { informally since July 2008, was formalized in 2012. Different regulatory agencies signed a } \\
\text { memorandum of understanding (MoU) for improved information sharing in } 2009 \text {. }\end{array}$ \\
\hline Malaysia & $\begin{array}{l}\text { Central Bank of Malaysia Act } 2009 \text { strengthened the BNM's financial stability objective. } \\
\text { Financial Stability Executive Committee (FSEC) was set up within the BNM in } 2010 \text { to make } \\
\text { recommendations to address risks to financial stability arising from entities outside BNM's } \\
\text { regulatory sphere. BNM also started reviewing its MoUs with other regulators to improve } \\
\text { supervisory coordination. }\end{array}$ \\
\hline Mexico & $\begin{array}{l}\text { Council of Financial System Stability (CESF) was established on } 29 \text { July 2010. It is a council } \\
\text { of regulators, presided by the Minister of Finance. }\end{array}$ \\
\hline Peru & Voluntary consultative committee of regulators was established in 2008. \\
\hline Philippines & $\begin{array}{l}\text { In early 2011, BSP created an internal Financial Stability Committee. Further, it started the } \\
\text { groundwork to establish the Financial Stability Coordination Council, formally launched } \\
\text { on } 2 \text { March 2014. The FSCC is a council of regulators. }\end{array}$ \\
\hline Russia & $\begin{array}{l}\text { In December 2010, a Working Group to Monitor Financial Market Conditions was } \\
\text { established under the Presidential Council. It was disbanded in } 2012 \text { and replaced by a } \\
\text { Financial Stability Council in July 2013. In the same month, Central Bank of Russia was given } \\
\text { an explicit financial stability mandate. }\end{array}$ \\
\hline South & A roundtable of regulators formed in 2008 to improve regulatory coordination. South \\
\hline Africa & rudential role. \\
\hline Thailand & $\begin{array}{l}\text { The Bank of Thailand Act B.R. } 2485 \text { (1942) was amended in } 2008 \text { to formalize and support } \\
\text { the adoption of a macroprudential approach. As a result, the financial stability committee } \\
\text { was set up, together with an operational definition of macroprudential policy. }\end{array}$ \\
\hline & $\begin{array}{l}\text { The Financial Stability Committee, a council of regulators, was established by the Decree in } \\
\text { Power of Law No: } 637 \text { dated } 8 \text { June } 2011 .\end{array}$ \\
\hline
\end{tabular}

Sources: IMF FSAP reviews and country reports, Central Bank websites, Ministry of Finance websites, FSB peer reviews, Silva (2016), Hemrit (2013), Riyanto (2016).

The rest of the paper is organized as follows. Section 2 discusses the data on capital controls. Section 3 reviews the literature on the two motivations for capital controls, and describes the new the mercantilism proxy. Section 4 describes the empirical strategy and the data on other macrofinancial variables. Section 5 describes the results and evaluation of the baseline models. Section 6 evaluates robustness of the main results. Section 7 concludes. 


\section{Measuring capital control actions}

I update the Pasricha et al. (2015) indices on capital control policy actions for 21 EMEs through 2015Q4. ${ }^{7}$ This dataset uses a narrative approach — reading the text of the policy changes or descriptions of such changes in other sources - and converting them into numerical measures that capture the direction of policy. Policy announcements often contain changes on multiple regulatory instruments. These are split and counted separately. A policy "change" or "action" in the dataset has a unique classification along six dimensions:

1. Inflow/Outflow

2. Easing/Tightening

3. Capital Control/Currency Based?

4. Prudential Type?

5. IIP Category (Foreign Direct Investment [FDI], Portfolio Investment, Other Investment, Financial Derivatives)

6. Quantitative/Price/Monitoring

The data are sourced from the text sections of the IMF AREAER, from the press releases, circulars and notifications on the regulators' and finance ministries' websites, Organisation for Economic Co-operation and Development (OECD) reports, news sources as well as other research papers. There are three main differences between the data used in this paper and the Pasricha et al. (2015) dataset. First, in this paper, I use the announcement dates of the changes, rather than their effective dates. Second, I drop changes that were preannounced by more than 60 days, as changes that have more than a 60-day implementation lag are likely to be more structural in nature, rather than imposed for macroeconomic and macroprudential management. Third, in this paper, I include changes that potentially affect both inflows and outflows (e.g., currency-based measures) on both the inflow and outflow sides. That is, these changes are counted twice.

In the baseline models, I use the weighted version of the dataset and exclude policy changes that affect FDI. In the weighted version of the Pasricha et al. (2015) dataset, each easing or tightening action is already identified as belonging to one of four IIP categories: FDI, Portfolio Investment, Financial Derivatives, and Other Investment. Each action is weighted by the share of the external assets (liabilities) of its IIP category in the total external assets (liabilities) of the country. Further, there are two versions of the weighted dataset: one that counts all actions, and the other that counts only non-FDI actions. The second version is used in the baseline models in this paper because it allows us to focus on actions that reflect macroeconomic or macroprudential concerns with capital flows, i.e., those focused on "hot

\footnotetext{
${ }^{7}$ A detailed description of the dataset and the dataset itself are available online as an appendix to the Pasricha et al. (2015) paper: http://www.nber.org/papers/w20822/. Please also see this appendix for a comparison of weighted and unweighted datasets.
} 
flows." When counting only the non-FDI related changes, the weights assigned are the relevant IIP category of the change divided by the total of the non-FDI categories (i.e., Portfolio Investment, Financial Derivatives, and Other Investment). This ensures that even for countries for which FDI is the largest category, policy actions that affect all "hot flows" are given the same weight (of 1) as similar actions by countries where FDI is a small share of the balance sheet.

Once the changes are identified and weighted, I add up the number of weighted inflow easings per time period (here, a week), number of weighted inflow tightening actions per week, and so on. I can then compute three variables that reflect the net direction of policy in a week. The first variable is the weighted net inflow tightening measures (number of weighted inflow tightening less easing actions per week). I also compute the weighted net outflow easing actions, used as a control variable as policy-makers can also use outflow easings to lean against net capital inflows. Finally, the sum of the two policy variables is what I call the "weighted net NKI restricting measures," which captures the overall direction of policy, i.e., on the net, the number of weighted measures on the inflow and outflow sides, which have the expected impact of reducing NKI.

Most of the paper focuses on explaining (weighted, non-FDI) net inflow tightening measures, as much of the policy debate and theoretical literature on macroprudential capital controls focuses on these restrictions. However, when exploring the choice of instruments, I also use the (weighted, non-FDI) net NKI restricting measures as the dependent variable.

Figure 1 plots the cumulated versions of weighted net inflow tightening actions and weighted net outflow easing measures for China and India, two countries with extensive and long-standing capital controls. The figure shows that on the whole, both countries have taken more liberalization actions than tightening actions since 2001 on both inflow and outflow sides, but it also shows periods of tightening of inflow restrictions (2004-05, 2007-08 and again 2010-11 for China) as well as periods of tightening of outflow restrictions (2015, also for China).

Not all emerging markets were equally active in changing capital controls policies (Figure 2). In the baseline models, I use the 11 most active countries, i.e., those that had at least 32 policy actions in the 15-year period, with at least one inflow tightening. ${ }^{8}$ This choice of sample is based on the nature of the exercise. Although very interesting, the question we are exploring here is not why some countries rely more on capital controls as policy tools (e.g., India, China, Brazil) and others not at all (e.g., Mexico, Egypt) - the answer may depend on the institutional arrangements and policy preferences in these countries as well as their international agreements (e.g., European Union rules for Hungary, Poland, Czech Republic; $\mathrm{OECD}$ rules for Mexico and Chile). The question we are exploring here is whether the actions of

\footnotetext{
${ }^{8}$ Full sample results are reported in the robustness checks section.
} 
countries that do use capital controls or currency-based measures are predictable based on certain macroeconomic and macroprudential variables.

Figure 1: Pasricha et al. (2015) indices of capital controls policy for China and India

(a) China

Higher values $=$ More openness

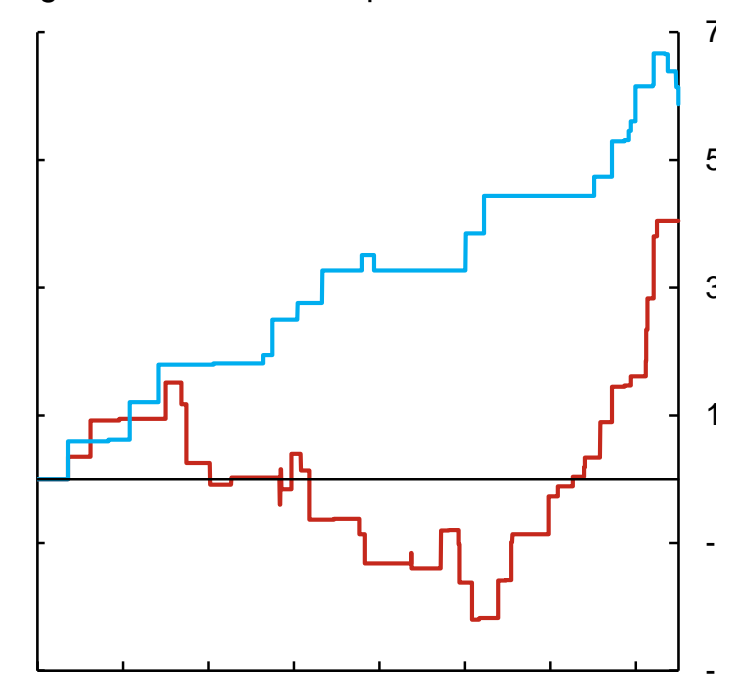

20012003200520072009201120132015

Cumulative Number of Weighted Net Outflow Easings (b) India

Higher values $=$ More openness

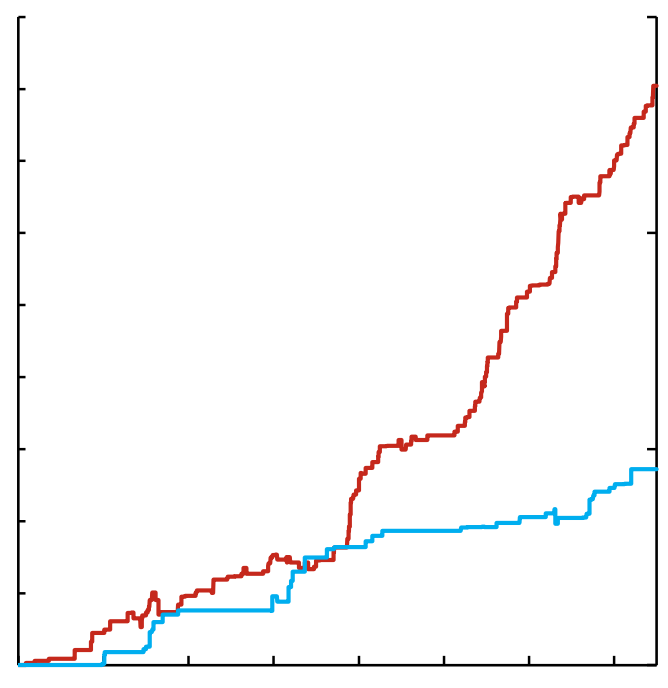

20012003200520072009201120132015

_ Cumulative Number of Weighted Net Inflow Easings

Last observation: 31 December 2015

Note: Figures include policy actions related to FDI.

Source: Authors' calculations

Figure 2: Baseline models include the 11 most active countries

Total Number of Policy Actions: 1 Jan 2001 - 31 Dec 2015

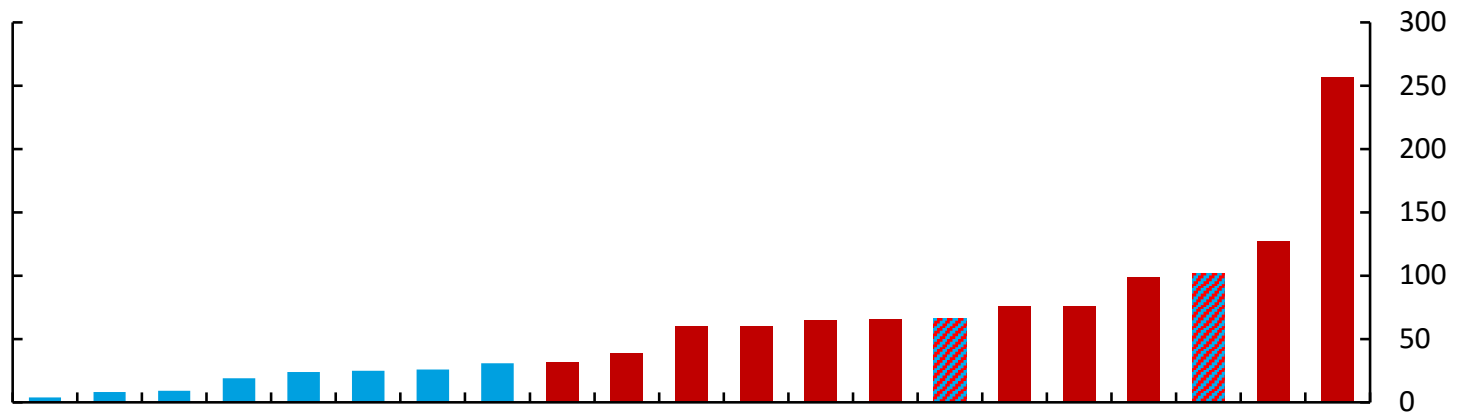

EGY CZE MEXMAR POL IDN CHL HUN RUS COL BRA PHL TUR THA ZAF ARG KOR CHN MYS PER IND 


\section{The motivations for capital inflow controls}

The literature identifies two main motivations for using inflow side capital controls: mercantilist and macroprudential. In this section, I survey the theoretical and empirical literature on each of these motivations to identify the testable hypothesis and variables that would represent each of the motivations in the empirical analysis. I also introduce the new mercantilism proxy that I use to delineate macroprudential from mercantilist motivations.

\section{Mercantilist motivation}

Mercantilist motivation can be understood as the strategy to promote export-led development by keeping the exchange rate undervalued, through a combination of capital controls and reserves accumulation (Dooley et al., 2003, 2014). A large empirical literature has tested the macroeconomic versus prudential motivations for foreign exchange reserves accumulation, a policy complementary to capital controls (Aizenman and Lee, 2007; Ghosh et al., 2012; Cheung and Qian, 2009; Jeanne and Ranciere, 2006). In this literature, export growth rates and exchange rate undervaluation relative to fundamental purchasing power parity value are used as proxies of mercantilist motivation, with higher levels of reserves associated with greater undervaluation and greater export growth. These regression specifications focus on explaining cross-country differences in levels of reserves and do not assume causality. If the mercantilist strategy is successful, one would expect countries that ended up accumulating larger reserves hoardings to have seen higher export growth and undervalued exchange rates. Yet this does not directly translate into a policy strategy: should countries intervene more (through reserves accumulation or capital controls) when export growth is high or when it is lagging?

Another variable that could reflect mercantilist motivation is suggested by Costinot, Lorenzoni and Warni (2014). In a two-country model, they find that from a mercantilist perspective, the optimal capital controls policy is countercyclical. In their model, a country growing faster than its trading partner has incentives to promote domestic savings by taxing capital inflows or subsidizing capital outflows, and vice versa. However, this model is a twocountry model, rather than a small open economy model, limiting its applicability to EMEs.

The literature therefore doesn't provide very clear guidance on identifying mercantilist motivation. The problem is further compounded when one is trying to delineate mercantilist from macroprudential motivation, as discussed below.

\section{Macroprudential motivation}

Macroprudential policy is defined by an objective - that of addressing systemic risks in the financial sector to ensure a stable provision of financial services to the real economy over time (BIS-FSB-IMF, 2011). In other words, the objective is to mitigate booms and busts in 
the finance cycle. Under this policy framework, capital controls could be considered tools of macroprudential policy if they specifically targeted the source of systemic risks from external finance, particularly those that cannot be addressed using other (non-residency-based) prudential tools.

Assessing whether capital controls have been used as macroprudential tools would necessitate the assessment of systemic risk buildups around the time that capital controls were changed, and also the assessment of whether these controls targeted the systemic risk. In the practitioner's guidebook, measures of systemic risk include, but are not limited to, credit-toGDP gap, levels or growth of foreign credit - in particular, foreign currency or short-term credit - asset price booms, etc.

The policy discussions on capital controls as macroprudential tools have engendered a growing theoretical literature, which allows us to form testable empirical hypotheses (Bianchi, 2011; Jeanne and Korinek, 2010; Benigno et al., 2011; Korinek, 2016; Schmitt-Grohe and Uribe, 2016). In general, these models recommend a tax on stocks rather than on flows. As the probability that the collateral constraint will bind increases with the level of debt, some models recommend that the capital controls be set to positive values once net foreign liabilities have crossed a threshold (Bianchi, 2011; Korinek, 2011). A testable hypothesis would then be that macroprudential inflow controls are tightened when the net foreign liabilities, particularly foreign currency debt liabilities, are above their country-specific historical average. Korinek (2016) finds that optimal capital controls are highest on dollar debt, followed by GDPlinked foreign currency debt, CPI-linked local currency debt, unindexed local currency debt and portfolio equity, in that order. Greenfield FDI is assumed not to create externalities, and therefore does not warrant restrictions or taxes.

\section{Disentangling mercantilist and macroprudential motivations in exchange rate management}

While policy-makers and economic theorists broadly agree on most measures of systemic risk that capital controls could legitimately respond to, as part of macroprudential policy, there is one crucial variable where there is some disagreement. This variable is the exchange rate. The policy-makers' approach to macroprudential capital controls specifically recommends that macroprudential policy not be burdened with additional objectives - for example, exchange rate stability or stability of aggregate demand or the current account (BISFSB-IMF 2011). Under this view of macroprudential capital controls, once the systemic risk variables are controlled for, the exchange rate changes (nominal or real) should not have additional explanatory power in an empirical specification.

In contrast, the recent theoretical literature on capital controls as macroprudential policy views the target of macroprudential policy more broadly, and encompasses targeting the REER. It views exchange rate appreciation as the channel that facilitates over-borrowing, especially foreign currency borrowing. The gist of these models is as follows: there is a 
pecuniary externality that agents do not take into account in their foreign borrowing decisions. This externality arises because the value of the collateral depends on the real exchange rate, which the agents take as given. However, the value of the real exchange rate itself depends on the aggregate borrowing decisions of the agents. Greater aggregate borrowing leads to real exchange rate appreciation, which increases the value of the collateral and therefore encourages further external borrowing. During a financial crisis, the reverse feedback loop operates, leading to boom-bust cycles in capital flows and credit. This theoretical literature suggests that optimal capital controls are countercyclical, i.e., increasing in the level of net external debt, whenever there is a positive probability of a future crisis (and zero when the level of debt is low). ${ }^{9}$ These models imply that simply finding that policy responds to exchange rate doesn't imply policy is mercantilist (or macroprudential). Note that in these models, the mercantilist motivation for capital controls is not explored. The only benefit of mitigating real exchange rate appreciation is mitigating external credit cycles. However, in practice, the mercantilist and macroprudential motivations may not be perfectly correlated. For example, net capital inflows (and exchange rate appreciation) may be high even when gross inflows are very low, because gross outflows are even lower. In this case, macroprudential motivation may not exist, as there is no excessive accumulation of foreign debt, while mercantilist motivation would exist.

In order to reconcile the policy and theoretical view, and as an additional tool to isolate the mercantilist motivation in exchange rate management, I propose a new proxy for mercantilist motivations. This proxy is the weighted exchange rate against the top five trade competitors. When the exchange rate is appreciating against trade competitors, the EME can be interpreted as losing competitiveness in the world market. The reason this proxy works is that the trade competitors of most EMEs in our sample are other EMEs, and most EMEs do not borrow in the currencies of their trade competitors. In the terminology of the recent literature, the collateral constraint is not denominated in the currencies of the trade competitors, rather in the base currencies (US dollar or euro). Therefore, while resisting appreciation against the base currency (US dollar or euro) per se could capture either mercantilist or macroprudential concerns, resisting appreciation against trade competitors should capture only the mercantilist motivation (I test this below).

I identify trade competitors as countries with the highest merchandise trade correlation index, developed by the United Nations Conference on Trade and Development (UNCTAD). ${ }^{10}$ Trade correlation index is a simple correlation coefficient between economy A's

\footnotetext{
${ }^{9}$ An exception is Schmitt-Grohe and Uribe (2016), who show that the Ramsey optimal policy is in fact pro-cyclical, where the tax rate starts to rise only when the debt contraction has already begun. This result seems to come from the assumption that the planner sets the tax level high enough such that the shadow value of collateral to individual is zero at all times. None of the papers cited, however, predict that optimal capital controls are acyclical to foreign credit.

${ }^{10}$ The UNCTAD trade correlation index is available on an annual basis from 1995 to 2012. I use the 2012 competitor countries for 2013-2015.
} 
and economy B's trade specialization index and can take a value from -1 to 1 . A positive value indicates that the economies are competitors in the global market since both countries are net exporters of the same set of products. A negative value suggests that the economies do not specialize in the production or consumption of the same goods, and are therefore natural trading partners. ${ }^{11}$ The specialization index removes bias of high export values because of significant re-export activities; thus, it is more suitable to identify real producers than traders. ${ }^{12}$

For each EME in our sample, I identify five countries with the highest trade correlation index in each year. Next, I compute quarterly the real exchange rate appreciation of the EME's currency against each of the five trade competitors, and construct five different indices: two nominal indices, two real indices, and one country-specific index that uses the series that is most relevant for each country.

The two nominal proxies are defined as follows:

(2) $\quad W A P P R Y_{i t}=\sum_{j=1}^{5} w_{j}\left[4\left(x_{i t}-L^{52} x_{i t}\right)-4\left(x_{j t}-L^{52} x_{j t}\right)\right]$

And the two real proxies are defined as:

$$
\begin{aligned}
& W R A P P R Q_{i t}=\sum_{j=1}^{5} w_{j}\left[4\left(x_{i t}-L^{13} x_{i t}\right)-4\left(x_{j t}-L^{13} x_{j t}\right)+\left(\pi_{i t-1}-\pi_{j t-1}\right)\right] \\
& W R A P P R Y_{i t}=\sum_{j=1}^{5} w_{j}\left[4\left(x_{i t}-L^{52} x_{i t}\right)-4\left(x_{j t}-L^{52} x_{j t}\right)+\left(\pi_{i t-1}-\pi_{j t-1}\right)\right]
\end{aligned}
$$

where $x_{i t}$ is the natural log of the nominal exchange rate against the US dollar for country $i$ as of the end of week $t$ (measured in USD per domestic currency unit), $L$ is the lag operator and $\pi_{i t}$ is the year-over-year change in consumer price index (CPI) as of week $t, w_{j}$ is the weight assigned to competitor $j$ and is measured by the trade correlation index between country $i$ and country $\mathrm{j}$ in week $\mathrm{t}$ (and is constant for all weeks in a calendar year). Note that the set of trade competitors (j) included in the calculation of the index may vary over time, but appears to be reasonably stable over five-year periods in the sample.

The nominal proxies measure the weighted nominal appreciation of a country's currency over the previous quarter (13 weeks, approximately) and over the previous year (52 weeks, approximately), respectively. The real proxies are analogously interpreted. All proxies express the appreciation at annual rates.

\footnotetext{
${ }^{11}$ Note that this index doesn't take into account the extent to which each country competes with its competitors in third party markets. For example, if India and China export the same products, but to different countries, they are not necessarily competing with each other and the yuan exchange rate would not matter as much for India. A real exchange rate index that also takes this competition in third markets into account is computed in IDB (2016).

12 A large and growing literature questions the ability of standard REER indices to capture changes in trade competitiveness, given the transformation of global trade because of emergence of global value chains. The existing REER indices do not control for trade in intermediate inputs, and impute the entire value of the export to the exporting country, even if the value added in that country is very small. Therefore, these indices do not capture well the true competitive pressures (Patel et al., 2017). The UNCATAD measure controls for the re-exporting activities and therefore allows us to better identify trade competitors than by using weights of standard REER indices.
} 
Finally, I compute a country-specific proxy, which uses for each country and each capital control index the mercantilism index that is most important for that country, i.e., most highly correlated with capital control changes. I use this in the baseline models, and generally refer to this as the "Mercantilism Proxy," unless otherwise specified. That is, I compute the countryspecific correlation coefficient (over the full sample period) between the weighted $W_{H N T I}$ and each of the four proxies defined above. Then that country's mercantilism proxy is the series with the highest correlation coefficient. I call this proxy $W A P P R_{i t}$, with the understanding that it uses a different series for each country for each capital control measure. The reason for creating a country-specific proxy and not focusing only on the real appreciation indices is that for countries where food or commodities are a large share of the consumption basket as well as of imports, policy-makers may focus more on the nominal exchange rate rather than on the real exchange rate, as total inflation is too volatile and depends on the nominal exchange rate itself.

Figure 3 plots the correlation coefficient between bank credit-to-GDP gap and the mercantilism proxy as well as with the nominal exchange rate appreciation against the US dollar. The figure shows that for the broad majority of countries, the correlation between bank credit gap, our main measure of macroprudential motivation, and the mercantilism proxy is low or negative, which is what we need for identification.

Figure 3: For most countries in sample, the bank credit-to-GDP gap and mercantilism proxy are uncorrelated or negatively correlated

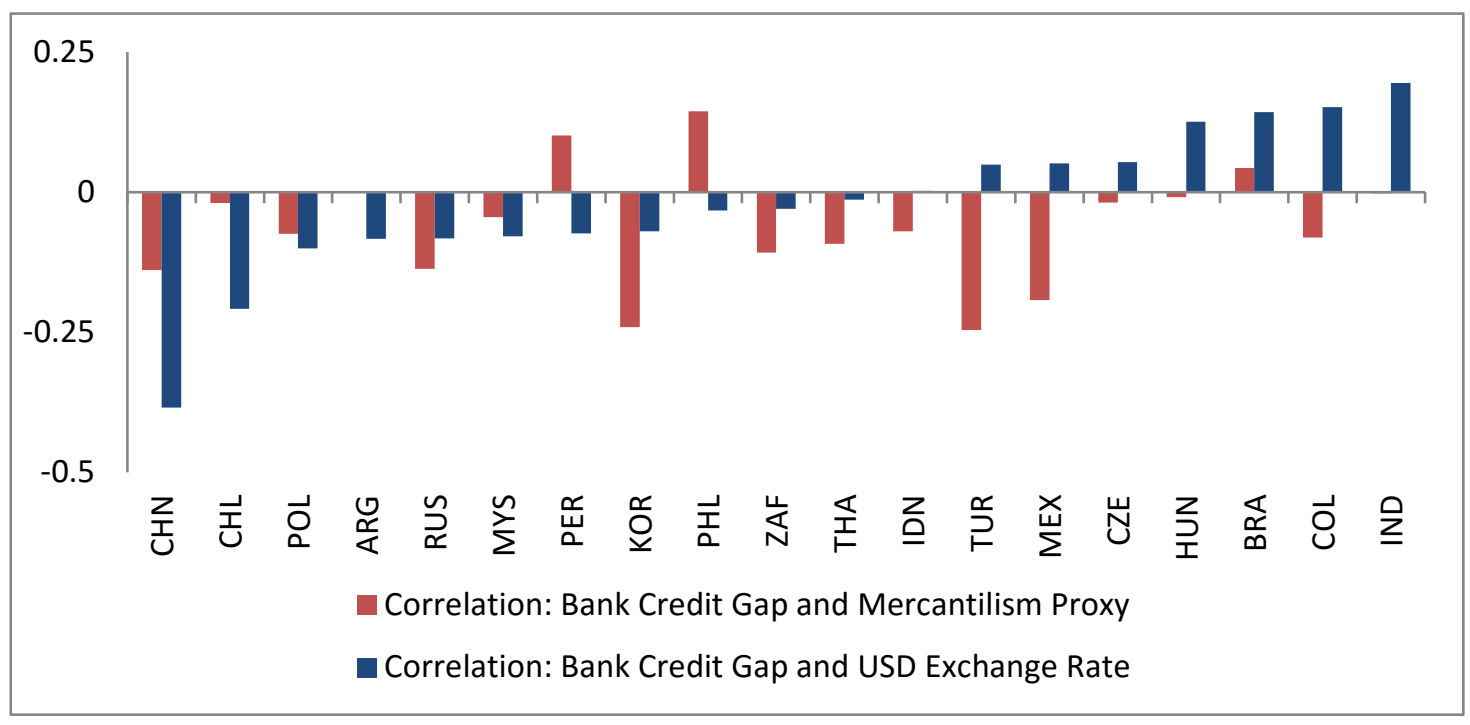

Notes: The mercantilism proxy used in the figure is the weighted real appreciation over the previous quarter. For data sources, please see Appendix Table A.1. 


\section{Methodology}

\subsection{Econometric methodology}

The capital controls actions series is an ordered variable. Positive values of the variable reflect tightening and negative values reflect easing. Further, the larger the absolute value of numbers associated with the tightening or easing, the larger the policy change. The ordered logit model is then a natural choice of model to predict policy actions. The ordered logit model assumes that there exists a continuous latent variable $\left(\mathrm{y}_{\mathrm{i}}^{*}\right)$ underlying the ordered policy responses that we observe $\left(\mathrm{y}_{\mathrm{i}}\right) \cdot{ }^{13}$ The two are related according to

$$
y_{i}=\left\{\begin{array}{ccc}
s_{1} & \text { if } & y_{i}^{*} \in\left(-\infty, c_{1}\right] \\
s_{2} & \text { if } \quad y_{i}^{*} \in\left(c_{1}, c_{2}\right] \\
& & \ldots \\
s_{K} & \text { if } & y_{i}^{*} \in\left(c_{K-1}, \infty\right)
\end{array}\right.
$$

where $i=1$ is the first policy action in the country sample (for example, net inflow tightening action), $i=2$ is the second policy action and $i=N$ is the last policy action measure and there are $k$ different discrete amounts by which the policy-makers may change controls. Also note that $\mathrm{c}_{1}<\mathrm{c}_{2}<\cdots<\mathrm{c}_{\mathrm{k}}$.

Let $\mathrm{w}_{\mathrm{i}}$ denote the vector of variables observed in the time period prior to the $i^{\text {th }}$ policy change that may have influenced the government's decision of how much to change policy. The unobserved latent variable depends on $\mathrm{w}_{\mathrm{i}}$ according to

$$
y_{i}^{*}=w_{i}^{\prime} \beta+\varepsilon_{i}
$$

where $\varepsilon_{i} \mid w_{i} \sim \operatorname{iid} N(0,1)$.

If $\Phi(\mathrm{z})$ denotes the probability that a logistic variable takes on a value less than or equal to $z$, then the probabilities that the target changes by $s_{j}$ can be written as follows:

$$
\operatorname{Pr}\left(y_{i}=s_{j} \mid w_{i}\right)=\left\{\begin{array}{cl}
\Phi\left(c_{1}-w_{i}^{\prime} \beta\right) \quad \text { for } j=1 \\
\Phi\left(c_{j}-w_{i}^{\prime} \beta\right)-\Phi\left(c_{j-1}-w_{i}^{\prime} \beta\right) & \text { for } j=2,3, \ldots k-1 \\
\ldots & \text { for } j=k \\
1-\Phi\left(c_{k-1}-w_{i}^{\prime} \beta\right) & \text { for } k
\end{array}\right.
$$

An ordered logit model estimates the parameters $\beta$ and $c_{j}$ through maximum likelihood methods. The conditional log likelihood function is

$$
\mathcal{L}(\beta, c ; y, w)=\sum_{t=1}^{T} \log q\left(y_{t} \mid \Upsilon_{t-1} ; \beta, c\right)=\sum_{i=1}^{N} l\left(y_{i} \mid w_{i} ; \beta, c\right)
$$

where $\Upsilon_{t}$ represents information observed through time t, i.e.,

$$
\Upsilon_{t}=\left(y_{t}, w_{t}, y_{t-1}, w_{t-1}, \ldots, y_{1}, w_{1}\right)
$$

\footnotetext{
${ }^{13}$ The model description and notation in this section largely follows Hamilton and Jorda (2002).
} 
and $l(\cdot)$ is the log of the probability of observing $y_{i}$ conditional on $w_{i}$.

The baseline model then is a panel ordered logit model, of the form

$$
\operatorname{Pr}\left(y_{i t}=s_{j} \mid w_{i t-1}\right)=f\left\{X_{i t-1}^{M P} \beta^{M P}+X_{i t-1}^{F X} \beta^{F X}+\mathrm{X}_{t}^{G} \beta^{G}+\mathrm{X}_{i t-1}^{O} \beta^{O}\right\}_{1}
$$

where $y_{i t}$ is the number of policy actions by country $i$ in quarter $t, \operatorname{Pr}\left(y_{i t}=s_{j} \mid w_{i t-1}\right)$ is the probability that country $i$ takes $s_{j}$ actions in week $t . \mathrm{X}_{i t-1}^{M P}$ and $\mathrm{X}_{i t-1}^{F X}$ are the variables representing macroprudential (MP) and mercantilist (FX) motivations, respectively. $\mathrm{X}_{t}^{G}$ controls for the global variables and $\mathrm{X}_{i t-1}^{O}$ controls for the other domestic policies that may be taken in conjunction with capital controls - for example, monetary and fiscal policy changes. In the baseline models, $y_{i t}$ refers to either (weighted, non-FDI) net inflow tightening actions or (weighted, non-FDI) net NKI restricting measures.

The greater the number of capital control actions, the more actively is the policy leaning against the cycle. The weighting scheme makes the number of policy actions per week almost a continuous variable, yet there is little difference in the strength of policy actions that are measured as, for example, 0.24 vs. 0.256 . In the baseline models, to reduce the number of ordered categories, the weighted capital controls variable is sorted into five bins, as follows:

$$
y_{i t}^{o}=\left\{\begin{array}{ccr}
-1 & \text { if } & y_{i t}<-0.5 \\
-0.5 & \text { if } & -0.5 \leq y_{i t} \leq 0 \\
0 & \text { if } & y_{i t}=0 \\
0.5 & \text { if } & 0<y_{i t} \leq 0.5 \\
1 & \text { if } & y_{i t} \geq 0.5
\end{array}\right.
$$

The baseline models estimate equation (5) for $\mathrm{y}_{\mathrm{it}}^{\mathrm{o}}$. This transformation does not affect the main conclusions, as discussed in the robustness checks, but makes the estimations a bit faster. The models are estimated using random effects, but the results are robust to adding country-specific dummies.

\section{Two stages in estimation}

The estimation takes places in two stages. In the first stage, I use my preferred measures of mercantilist and macroprudential motivations, described in more detail in section 4.2 below. Given the recent literature on global financial cycles and the concerns emergingmarket policy-makers have raised about the push factors in capital flows, I compare the baseline models with a VIX-only model (with no domestic variables). I also compare the baseline models with models that include only (country-specific) mercantilism proxy and the model that includes only the preferred macroprudential proxy (as well as other domestic policies). I compare these models using the area under the receiver operating characteristic (AUROC) curves and other model comparison criteria, described in section 4.3 below.

In the second stage, I extend the baseline model by sequentially adding variables capturing mercantilist and macroprudential motivations, and test whether these additional 
variables improve the model predictions. I use an exhaustive list of macrofinancial variables in this step, described in section 4.2 below.

\subsection{Macrofinancial data}

\section{Stage 1: Baseline models}

In the baseline model, I use one of the five mercantilism proxies to capture mercantilist motivations. For the macroprudential motivation, I use the bank credit-to-GDP gap. This variable is defined as the deviation from a backward-looking HP-filtered trend of the ratio of domestic bank credit to private non-financial sector to GDP. The data on bank credit is from the Bank for International Settlements (BIS). The reason for choosing this variable as the main macroprudential variable is that it is viewed as a key indicator of systemic risk in the Basel III agreement. ${ }^{14}$ The recent early warning literature on financial crises - for example, Jorda, Schularick and Taylor (2012) - also highlights the importance of bank credit as a measure of systemic risk.

To capture common effects $\left(X_{t}^{G}\right)$, the baseline model includes the Chicago Board of Options Exchange Volatility Index (VIX). In robustness checks, I also control for the BIS global liquidity measure (cross-border bank claims for the world as percentage of global GDP) and the all-commodity prices index from the International Monetary Fund (IMF).

For the domestic policy variables $\left(\mathrm{X}_{\mathrm{it}-1}^{\mathrm{O}}\right)$, as in Hamilton and Jorda (2002), all regressions include an indicator variable that takes the value +1 if the previous policy action (whenever it was) was a tightening and -1 if the previous policy action was an easing. This variable captures the cycles in policy. In addition, I control for other domestic policies that are substitutes for or complements to capital control changes. To capture monetary policy stance, I use a dummy variable that takes the value 1 if the policy rate is increased in the quarter, 0 if there is no change in policy rate between the current and the previous quarter, and - 1 if monetary policy is eased in the current quarter. As an increase in interest rates can make capital inflows more attractive, policy-makers concerned about the value of the currency may simultaneously tighten inflow controls to curb the resulting appreciation pressures. A dummy for fiscal stance is similarly defined as takes the value +1 if the general government structural balance (as \% of potential output) increased in the given quarter (reflecting tightening of fiscal policy), -1 if the fiscal stance eased, and 0 otherwise. I also include a crisis dummy, which equals 1 for the global financial crisis (2008Q4) and for three domestic crises in Argentina (2001Q1-2003Q4), Russia (2001Q1-2001Q4) and Turkey (2001Q1-2004Q1).

\footnotetext{
${ }^{14}$ Basel III recommends using the broadest measure of credit possible. BIS makes available data on total credit gap, which includes credit from external sector. However, the time series on this variable starts late in the sample (after 2005 or even 2008) for many EMEs. Therefore, I use the narrower measure in the baseline models.
} 
As a robustness check, I also control for other domestic macroprudential policies, creating a variable that is the total number of domestic macroprudential measures taken (summing up the components from Cerutti et al. (2016), excluding the foreign currency reserves requirement measures, as the latter are already included in the capital controls data).

A note on the frequency of the variables is in order. Exchange rates (and other financial variables used in the second stage) are available at a weekly frequency. However, many of the macro variables are available at a quarterly or lower frequency. These are interpolated to weekly frequency using linear interpolation. An alternative would have been to use the last available value, but that could mean using observations that are no longer relevant for policy decisions. Further, policymaking is a forward-looking activity. The literature on assessing motivations for changes in monetary policy suggests that the results using only lagged variables to explain policy may be biased if policy-makers anticipate future evolution of variables and act on that information: policy-makers may not only change capital controls in response to past changes in economic variables, but also respond to their expectations of future evolution of these (Ramey, 2016). The literature on Taylor Rules addresses this by using Fed's Greenbook forecasts (Monokroussous, 2011 and others). However, such forecasts made by EME policy-makers are not available. The interpolations assume that policy-makers had information about the evolution of the economy that is not reflected in the previous quarter's data, and that their forecasts are accurate on average..$^{15}$ The data are collected from IMF BOPS, IMF WDI and GEM, UNCTAD, BIS macrofinancial database, Haver and national sources. A full list of variable definitions and sources is in the appendix.

\section{Stage 2: Extending the baseline model — additional variables}

In the second stage, I extend the baseline model by sequentially adding variables capturing mercantilist and macroprudential motivations, and test whether these additional variables improve the model predictions. I use an exhaustive list of macrofinancial variables in this step. For these variables, I consider their growth rates over the previous 13 weeks (approximately a quarter) and the previous 52 weeks (year over year), as well as deviations from short- and long-term trends (with trends computed as lagged 10-year moving average or from one-sided backward-looking HP-filter) to identify measures of "excess" that policymakers can be expected to respond to.

I use additional measures of vulnerabilities in the domestic and external sectors to capture macroprudential motivation. On the domestic side, I use different transformations of equity prices, residential property prices as well as measures of growth rates of bank credit to GDP, to capture vulnerabilities. On the external sector, I use BIS international debt securities statistics to create measures of excess in stocks and net issuance of foreign securities (total,

\footnotetext{
${ }^{15}$ As a robustness check, I repeat the analysis using quarterly data, for which most variables do not need to be interpolated. The results are robust to using lower frequency data.
} 
foreign currency and short-term, respectively). Further, I create a measure of total external credit raised by the domestic non-financial sector from foreign banks and debt securities by adding information from BIS locational banking statistics to the international debt securities data, as in Avdjiev et al. (2017).

To capture mercantilist motivation, in the extended models, I use measures of relative GDP growth (real GDP growth in the EME less world real GDP growth), growth in index of industrial production for the manufacturing sector (actual and relative to other EMEs) and export growth. Summary statistics of all variables are provided in Appendix Table A.2.

\subsection{Model evaluation}

I evaluate the models using two standard criteria for assessing predictive ability of the model: the rank probability scores and the AUROC.

The rank probability score (RPS) is a generalization of the Brier's quadratic probability score (QPS) for ordered outcomes. The Brier score summarizes the accuracy of binary forecasts. For ordered outcomes with multiple events, the rank probability score assesses how far the probability forecasts are from the observed events. That is, even when the forecast doesn't predict the accurate event, the RPS gives credit to models that were closer to the actual event. Let $\mathrm{K}$ be the number of forecast categories to be considered (five in this paper). ${ }^{16}$ For a given probabilistic forecast-observation pair, the ranked probability score is defined as

$$
\mathrm{RPS}=\sum_{\mathrm{k}=1}^{\mathrm{K}}\left(\mathrm{Y}_{\mathrm{k}}-\mathrm{O}_{\mathrm{k}}\right)^{2}=(\mathrm{Y}-\mathrm{O})^{2}
$$

where $\mathrm{Y}_{\mathrm{k}}$ and $\mathrm{O}_{\mathrm{k}}$ denote the kth component of the cumulative forecast and observation vectors $Y$ and $O$, respectively. That is, $Y_{k}=\sum_{i=1}^{k} y_{i}$, where $y_{i}$ is the probabilistic forecast for the event to happen in category $i$, and $\mathrm{O}_{\mathrm{k}}=\sum_{\mathrm{i}=1}^{\mathrm{k}} \mathrm{o}_{\mathrm{i}}$ if the observation is in category $\mathrm{i}$, and $\mathrm{o}_{\mathrm{i}}=0$ if the observation falls into a category $j \neq i$. The closer the RPS is to zero, the better the model predictions.

The receiver operating characteristic (ROC) curve evaluates the binary classification ability of a model, and has recently been used in early warning literature (Schularick and Taylor, 2012). Let $\widehat{y *}$ be the linear prediction of the latent variable from a binary logit model (i.e., one with a $0 / 1$ dependent variable). Let predicted outcome be 1 whenever $\widehat{y^{*}}$ crosses a threshold $\mathrm{c}$. That is, the predicted outcome $=\mathrm{I}(\widehat{\mathrm{y} *}-\mathrm{c}>0)$, where $\mathrm{I}($.$) is the indicator function.$ Then, for a given $c$, one can compute the true positive rate $\operatorname{TP}(c)$ (i.e., the percentage of " 1 " observations that are correctly predicted to be "1") and the false positive rate, $\operatorname{FP}(c)$ (i.e., the percentage of 0 observations that are incorrectly predicted to be 1). The ROC plots the true positive rate, $\operatorname{TP}(c)$, against the false positive rate, $\mathrm{FP}(\mathrm{c})$, for all possible thresholds $c$ on the real

\footnotetext{
${ }^{16}$ The description of RPS in this section follows Weigel et al. (2007).
} 
line. The plot is a unit square, as both $\mathrm{TP}(\mathrm{c})$ and $\mathrm{FP}(\mathrm{c})$ vary from 0 to 1 . Any point in the upper left triangle of the square (formed above a 45-degree line from the left corner of the square) has a higher true positive rate than a false positive rate. Therefore, an informative model is one where the ROC curve lies above the 45-degree line, that is, $\operatorname{TP}(c)>\operatorname{FP}(c)$ for all thresholds $c$ and the model always makes better predictions than the null of a coin toss. The closer the ROC curve is to the top left corner of the square, the better the model. The area under the ROC curve is greater than 0.5 for models with predictive ability.

The ROC curve assesses binary classifier, but the ordered logit model allows for multiple outcomes (five in this paper). Therefore, I compute five logit models, each with dichotomous dependent variable, to evaluate the baseline model in the first stage. The first model estimates a panel logit model, assessing the probability of the most negative outcome $\left(y_{i t}^{o}=-1\right)$ against all others. The second model predicts a binary indicator that equals 1 when $y_{i t}^{o}=-0.5$ and 0 otherwise, and so on.

I assess the baseline model against the VIX-only model, macroprudential-only (MPonly) model and mercantilism-only (FX-only) models using the ROC approach. In the second stage, as the number of models is quite large, I use only the RPS score to compare models.

\section{Empirical results}

The results indicate that emerging markets respond equally to mercantilist and macroprudential motivations when changing capital controls policies. Inflow controls policy is systematic, well captured by two variables: appreciation against trade competitors and domestic credit gap. However, inflow policy doesn't respond to the specific macroprudential concerns highlighted by recent theoretical literature: inflow policy is countercyclical to domestic bank credit to private non-financial sector, but is acyclical or procyclical to various measures of foreign credit. The reason for this is that foreign currency debt and external credit appear to be substituting for domestic bank credit, so that policy encourages foreign borrowing when domestic bank lending slows.

EMEs use both inflow tightening and outflow easing to respond to mercantilist concerns. The capital controls policy response is stronger in countries with high exchange rate pass-through to export prices, i.e., those whose exports stand to suffer more because of currency appreciation. Macroprudential motivations in capital controls policies became stronger after countries improved their institutional arrangements for macroprudential governance. 


\subsection{Baseline results: mercantilist and macroprudential motivations in use of inflow tightening policies}

Table 3 presents the results of the baseline model explaining (weighted, non-FDI) net inflow tightening. The reported coefficients are proportional odds ratios. A one-standarddeviation increase in the country-specific mercantilism proxy, other things being equal, increases the odds of taking a strong net inflow tightening measure by $33 \%$, compared with the alternatives (taking a small net inflow tightening measure, doing nothing or net easing of inflow controls). The results with other mercantilism proxies are similar - a one-standarddeviation nominal appreciation against trade competitors over the previous 13 weeks increases the odds of taking a net inflow tightening measure by $27 \%$, compared with the alternatives. The estimated coefficients for mercantilism proxies are all significant at $1 \%$ level of significance.

On the macroprudential side, a one-standard-deviation increase in bank credit to GDP gap has a similar effect. It increases the odds of a net inflow tightening by about $30 \%$ relative to the odds of the alternatives, other things being equal. The estimated coefficients for the bank-credit-to-GDP gap are also significant at $5 \%$ or $1 \%$ levels in all specifications.

The final row in Table 3 presents the results with the nominal exchange rate against the US dollar as a measure of mercantilist motivations. The US dollar plays an outsize role in trade invoicing and is often the focus of EME policy-makers' currency stabilization efforts. ${ }^{17}$ US dollar appreciation has a stronger impact on the likelihood of policy action than any of the mercantilist proxies, even after controlling for macroprudential motivations. This suggests that there is some part of variation in the exchange rate against the US dollar that is not captured either by the mercantilist or macroprudential proxies and may reflect a mix of the two factors, or some other factors, for example, macroeconomic management.

Like monetary policy, capital controls policy changes also come in cycles - a net inflow tightening increases the probability that the next action will be a net tightening as well - and the odds ratio increases by about $30 \%$. Net tightening of capital controls also comes with improvements in general government structural balances. Monetary policy stance and VIX are not significantly correlated, associated with the probability of net inflow tightening measures, but inflow tightening measures are significantly less likely to be used during crisis periods. The last column of Table 3 shows the model with mercantilism proxies replaced by nominal 13-week appreciation against the US dollar. It suggests that the US dollar rate plays a special role in EME policy-making, which is not fully captured by macroprudential or mercantilist motivations.

\footnotetext{
${ }^{17}$ Casas et al. (2016) document how a majority of global trade is invoiced in US dollars. Shambaugh (2004) documents that 139 out of 177 countries studied had the US dollar as their base currency.
} 
As the capital controls index is based on qualitative information, one may ask how the interpretation of results is affected if the intensity of the changes is not perfectly captured. The dataset on capital controls captures the intensity of changes in two ways: (1) the capital controls data identifies the changes at a granular level - policy announcements are not the same as policy actions. A policy action is identified by splitting announcements along six dimensions, meaning that if policy-makers were making bigger, "more intense" announcements in certain periods, e.g., during crisis periods, this should result in more counted actions in these periods. This is in fact the case with the index, as seen in Figure 7. Second, the index weights the actions by the share of the IIP category that the action affects, thus giving more weight to actions that affect a larger share of the country's balance sheet. However, to the extent that the data don't capture intensity perfectly, we may underestimate the size of the responses (if policy-makers systematically tightened more intensely than they eased, and we don't have that information). Therefore, we may interpret the results as capturing the minimum policy reaction. In this context, the finding that capital controls policy did react to mercantilist and macroprudential motivations gains even more significance, as the true coefficients may be even larger.

Table 3: Baseline - Inflow controls respond to both mercantilist and macroprudential concerns

Dependent Variable: Weighted Net Inflow Tightenings (non-FDI)
(1)
(2)
(3)
(4)
(5)
(6)

\begin{tabular}{lccccccc}
\hline Mercantilism Proxy (Country-Specific) & $1.33^{\star \star \star}$ & & & & & \\
Mercantilism Proxy (Nominal, 13-wk appr., \%) & & $1.27^{\star \star \star}$ & & & & \\
Mercantilism Proxy (Real, 13-wk appr., \%) & & & $1.26^{\star \star}$ & & & \\
Mercantilism Proxy (Nominal, yoy appr., \%) & & & & $1.27^{\star \star \star}$ & & \\
Mercantilism Proxy (Real, yoy appr., \%) & & & & & $1.24^{\star \star \star}$ & \\
Exchange Rate vs. USD (Nominal, & & & & & & \\
13-wk appr., \%) & & & & & & $1.42^{\star \star \star}$ \\
Bank Credit-GDP Gap (\%) & $1.29^{\star \star \star}$ & $1.30^{\star \star \star}$ & $1.31^{\star \star}$ & $1.28^{\star \star}$ & $1.30^{\star \star}$ & $1.28^{\star \star \star}$ \\
Previous Policy Action (T, E) & $1.32^{\star \star \star}$ & $1.33^{\star \star \star}$ & $1.32^{\star \star \star}$ & $1.33^{\star \star \star}$ & $1.32^{\star \star \star}$ & $1.31^{\star \star \star}$ \\
Fiscal Stance & $1.16^{\star \star \star}$ & $1.15^{\star \star}$ & $1.15^{\star \star \star}$ & $1.15^{\star \star \star}$ & $1.15^{\star \star \star}$ & $1.14^{\star \star}$ \\
Monetary Stance & $0.86^{\star}$ & 0.89 & 0.88 & 0.87 & 0.86 & 0.92 \\
VIX & 0.99 & 0.99 & 0.99 & 0.99 & 0.99 & 1.00 \\
Crisis Dummy & $0.33^{\star}$ & $0.28^{\star \star}$ & $0.28^{\star \star}$ & $0.30^{\star}$ & $0.30^{\star}$ & 0.47 \\
\hline Observations & 7,448 & 7,448 & 7,448 & 7,448 & 7,448 & 7,448 \\
Number of Countries & 11 & 11 & 11 & 11 & 11 & 11 \\
Pseudo-Log Likelihood & -1712 & -1715 & -1716 & -1716 & -1716 & -1706 \\
Chi-Squared (All Coefficients =0) & 73.55 & 68 & 76.12 & 60.21 & 60.67 & 87.54 \\
P-value (Chi-Squared) & 0 & 0 & 0 & 0 & 0 & 0 \\
\hline
\end{tabular}

Notes: Reported values are proportional odds ratios. Sample period is 2001w1-2015q52. All domestic control variables are oneweek lagged. All continuous domestic variables are standardized but centred at 0 , i.e., the variables are divided by their standard deviation but not demeaned. Monetary policy stance and fiscal policy stance are variables that take the value +1 if monetary policy is tightened in the previous week (or structural balance improves), -1 for expansionary policies and 0 otherwise. Robust standard errors used. ${ }^{* *} p<0.01,{ }^{* *} p<0.05,{ }^{*} p<0.10$ 
Our interest is not only in the statistical significance of coefficients of interest, but in the ability of the baseline model to predict policy. For this, one needs to evaluate the predictions of the model and compare them with those of alternative (perhaps simpler) models. One may ask, for example, how good the model is compared with a model with only mercantilist or only macroprudential motivations. Recent literature has highlighted the role of global factors in determining emerging market capital flows - in particular, VIX. Therefore, in Table 4, I evaluate the baseline model (with the country-specific mercantilism proxy) against these alternative models, using the RPS as well as the pseudo-log likelihood. The table shows that the baseline model performs better than all the others - with improvements in log likelihood, as well as rank probability score.

Table 4: Comparing models - Baseline model is better than VIX-only, mercantilist- or macroprudential-only models

\begin{tabular}{|c|c|c|c|c|c|}
\hline & \multicolumn{5}{|c|}{ Dependent Variable: Weighted Net Inflow Tightenings (non-FDI) } \\
\hline & (1) & (2) & (3) & (4) & (5) \\
\hline Model name: & Baseline & VIX only & $\mathrm{VIX+}$ & FX-only & MP-only \\
\hline Mercantilism Proxy (Country-Specific) & $1.33^{\star \star \star}$ & & & $1.34^{\star \star \star}$ & \\
\hline Bank Credit-GDP Gap (\%) & $1.29 \star \star \star$ & & & & $1.29^{\star *}$ \\
\hline VIX & 0.99 & 0.99 & 0.99 & 0.99 & 0.99 \\
\hline Previous Policy Action (T, E) & $1.32^{\star \star \star}$ & & $1.32^{* \star \star}$ & $1.33^{\star \star \star}$ & $1.31^{\star \star \star}$ \\
\hline Fiscal Stance & $1.16^{\star \star \star}$ & & $1.14^{* *}$ & $1.15^{\star \star}$ & $1.16^{\star \star \star}$ \\
\hline Monetary Stance & $0.86^{\star}$ & & 0.87 & $0.86^{*}$ & 0.87 \\
\hline Crisis Dummy & $0.33^{\star}$ & $0.39 \star \star \star$ & $0.29^{*}$ & 0.34 & $0.30^{\star}$ \\
\hline Observations & 7,448 & 8,424 & 7,448 & 7,448 & 7,448 \\
\hline Number of Countries & 11 & 11 & 11 & 11 & 11 \\
\hline Pseudo-Log Likelihood & -1712 & -1831 & -1731 & -1720 & -1723 \\
\hline Rank Probability Score & 0.06379 & 0.0643 & 0.06413 & 0.06406 & 0.06393 \\
\hline Chi-Squared (All Coefficients =0) & 73.55 & 26.54 & 43.73 & 45.75 & 54.89 \\
\hline P-value (Chi-Squared) & 0.00 & 0.00 & 0.00 & 0.00 & 0.00 \\
\hline
\end{tabular}

While the aggregate statistics are useful summaries of model performance, they average over predictions of no change as well as change. As there are a large number of weeks 
when policy did not change (the broad majority of observations), these summary statistics may not fully reflect the improvements in predicting policy actions across models. Therefore, it is instructive to look at the actual versus predicted values from the different models. Figure 4 plots the actual policy actions versus the predicted values of the latent variable from the baseline and VIX-only models defined as in Table 4, for four major economies: India, China, Brazil and Turkey. The figure shows that the latent variables co-move remarkably well with actual inflow policy actions. The VIX-only model, whose predictions will be the same for all countries, except the dip in the country-specific crisis periods, does not explain the level of direction of policy well.

Figure 4: Predicted latent variable has a high degree of co-movement with actual net inflow tightening actions

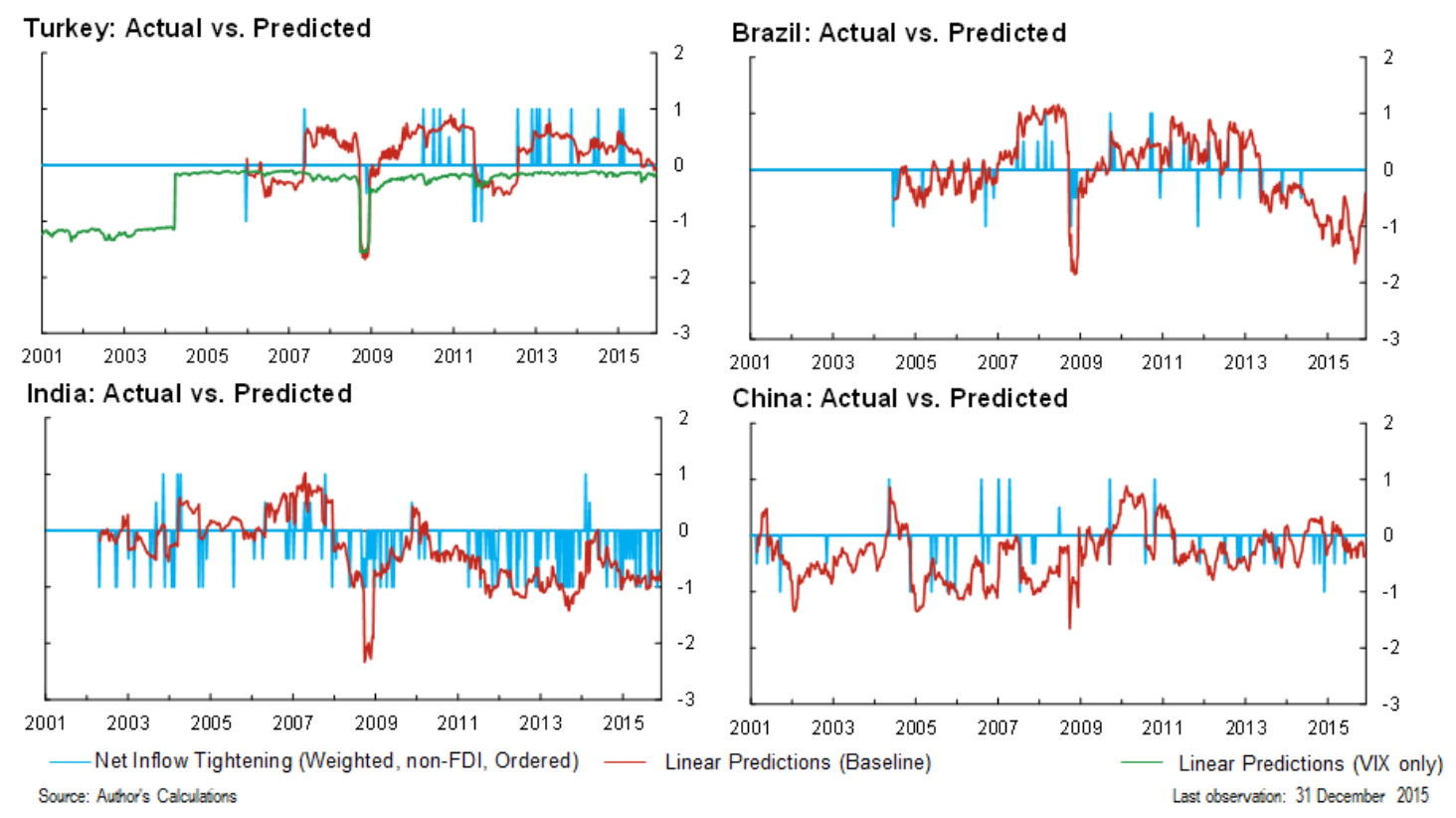

As a further assessment of the models, I compute the ROC curves and test whether the AUROC is significantly different across models. Table 5 computes the AUROC for the different models and tests their significance. The AUROC for the baseline model varies between 0.69 and 0.71 for predicting policy actions (i.e., excluding models predicting ordered (weighted, non-FDI) net inflow tightening $=0$ ) with standard errors of about 0.03 . This is better than a coin toss, though lower than a perfect predictor, which would have an AUROC of 1. However, these AUROCs are similar to those achieved in the recent models for crisis prediction, e.g., the baseline models in Schularick and Taylor (2012). This suggests that the baseline model does reasonably well as a predictor of capital controls policy.

Both MP-only and FX-only models are better than a coin toss and better than a VIXonly model, suggesting that each of the domestic factors plays a role in policy decisions. The 
baseline model improves over an MP-only or FX-only model in terms of AUROC, though the extent of improvement depends on the outcome being predicted. The FX-only models have an AUROC of between 0.6 and 0.69 , with the highest AUROC for predicting strong tightening of inflow controls or strong easing of controls. For the strongest tightening, the FX-only model is indistinguishable from the baseline model, suggesting that mercantilist motivations play a role when policy-makers decide to act decisively to tighten inflow controls. Mirroring these are the results for MP-only models. The AUROC for MP-only models are closer to the baseline model than the FX-only model for all except the strongest inflow tightening.

To illustrate the differences between models, Figure 5 plots the ROC curves for the baseline model, against those of FX-only and MP-only models. Recall that the closer the ROC curve is to the top left corner of the square, the better the model. The figure shows that all models give better predictions of policy actions than a coin toss. The baseline model in general has better predictions than the FX-only or MP-only models.

Table 5: Comparing models predicting inflow controls - AUROC

\begin{tabular}{|c|c|c|c|c|c|c|c|}
\hline & $\mathrm{N}$ & AUROC & Std. Err. & \multicolumn{2}{|c|}{ [95\% Conf. Interval] } & $x^{2}$ & $\mathrm{p}$-value \\
\hline \multicolumn{8}{|c|}{ Ordered (Weighted, non-FDI) Net Inflow Tightening = -1 } \\
\hline Baseline & 7448 & 0.72 & 0.03 & 0.66 & 0.78 & \multicolumn{2}{|c|}{. } \\
\hline VIX-Only & 7448 & 0.56 & 0.03 & 0.49 & 0.62 & 21.5 & 0.00 \\
\hline FX-Only & 7448 & 0.67 & 0.03 & 0.62 & 0.73 & 6.43 & 0.01 \\
\hline MP-Only & 7448 & 0.7 & 0.03 & 0.65 & 0.76 & 1.97 & 0.16 \\
\hline \multicolumn{8}{|c|}{ Ordered (Weighted, non-FDI) Net Inflow Tightening = -0.5} \\
\hline Baseline & 7448 & 0.64 & 0.03 & 0.59 & 0.69 & \multicolumn{2}{|c|}{. } \\
\hline VIX-Only & 7448 & 0.55 & 0.03 & 0.5 & 0.61 & 7.54 & 0.01 \\
\hline FX-Only & 7448 & 0.6 & 0.02 & 0.55 & 0.65 & 9.28 & 0.00 \\
\hline MP-Only & 7448 & 0.65 & 0.03 & 0.6 & 0.7 & 0.29 & 0.59 \\
\hline \multicolumn{8}{|c|}{ Ordered (Weighted, non-FDI) Net Inflow Tightening = 0} \\
\hline Baseline & 7448 & 0.55 & 0.02 & 0.51 & 0.58 & \multicolumn{2}{|c|}{. } \\
\hline VIX-Only & 7448 & 0.52 & 0.02 & 0.49 & 0.55 & 1.55 & 0.21 \\
\hline FX-Only & 7448 & 0.51 & 0.02 & 0.48 & 0.54 & 3.48 & 0.06 \\
\hline MP-Only & 7448 & 0.55 & 0.02 & 0.51 & 0.58 & 0.03 & 0.86 \\
\hline \multicolumn{8}{|c|}{ Ordered (Weighted, non-FDI) Net Inflow Tightening = 0.5} \\
\hline Baseline & 7448 & 0.71 & 0.03 & 0.64 & 0.77 & \multicolumn{2}{|c|}{. } \\
\hline VIX-Only & 7448 & 0.5 & 0.03 & 0.44 & 0.57 & 21.64 & 0.00 \\
\hline FX-Only & 7448 & 0.62 & 0.03 & 0.56 & 0.68 & 12.66 & 0.00 \\
\hline MP-Only & 7448 & 0.7 & 0.03 & 0.63 & 0.76 & 0.53 & 0.47 \\
\hline \multicolumn{8}{|c|}{ Ordered (Weighted, non-FDI) Net Inflow Tightening = 1} \\
\hline Baseline & 7301 & 0.69 & 0.03 & 0.63 & 0.75 & \multicolumn{2}{|c|}{. } \\
\hline VIX-Only & 7301 & 0.5 & 0.03 & 0.43 & 0.56 & 17.04 & 0.00 \\
\hline FX-Only & 7301 & 0.69 & 0.03 & 0.63 & 0.75 & 0.34 & 0.56 \\
\hline MP-Only & 7301 & 0.66 & 0.03 & 0.59 & 0.72 & 2.51 & 0.11 \\
\hline
\end{tabular}

Notes: Each model is panel logit, with the dependent variable redefined to be a dichotomous variable. For example, in the first block of models, the dependent variable takes value 1 when the ordered (weighted, non-FDI) net inflow tightening variable $=-1$, and 0 otherwise. The final model has fewer observations because for at least one country in the sample, the model with the crisis dummy perfectly predicts action. These observations are dropped. 
Figure 5: Comparing models using receiver operating characteristic curves
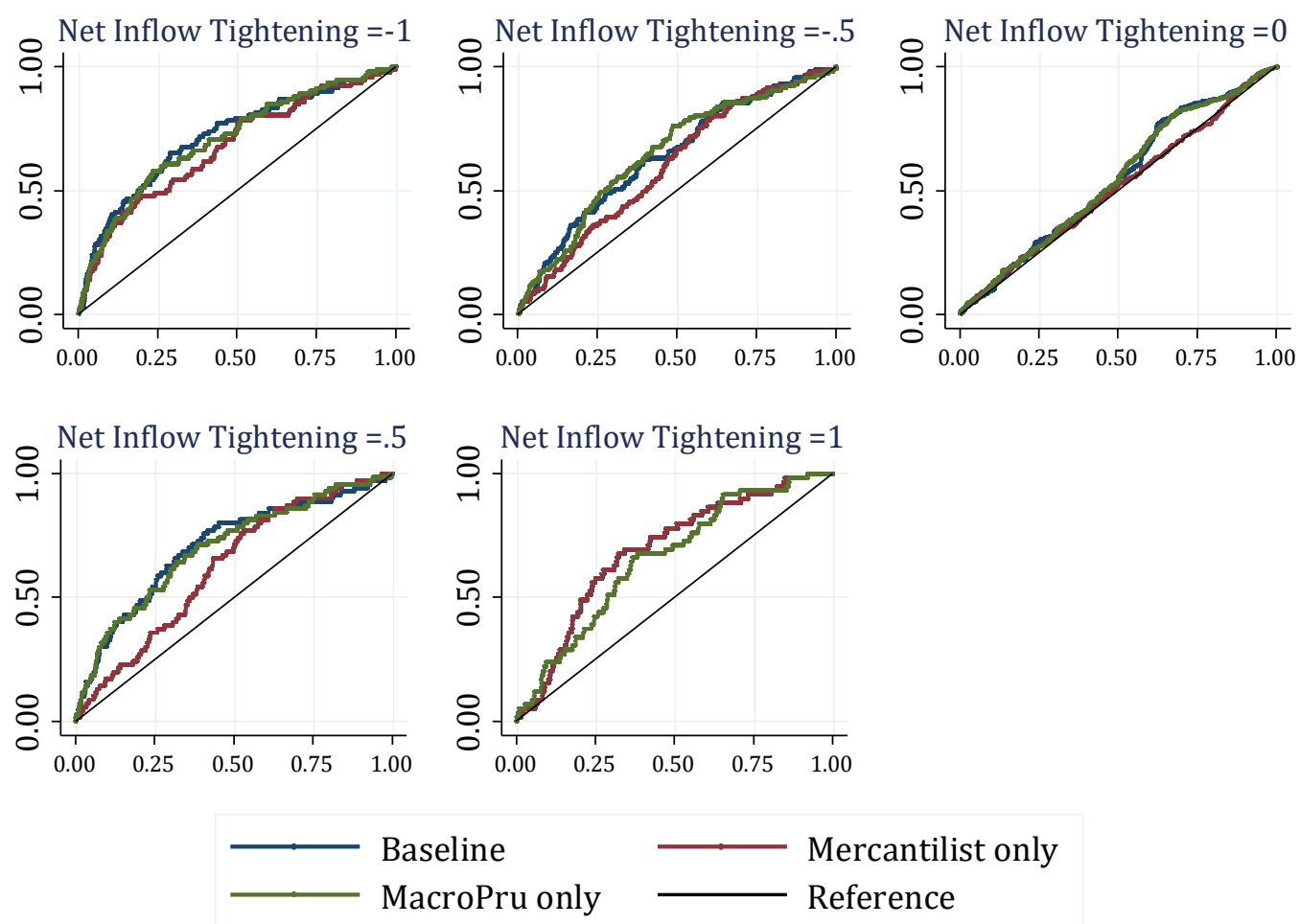

Notes: Each model is panel logit, with dependent variable redefined to be a dichotomous variable. For example, in the top left panel the dependent variable takes value 1 when the ordered (weighted, non-FDI) net inflow tightening variable $=-1$, and 0 otherwise. The vertical axis plots the true-positive rate and the horizontal axis the false positive rate for each value of the cut-off probability c, above which the model is assumed to predict an event (1).

To summarize, the results so far suggest that both mercantilist and macroprudential motivations are important in predicting the use of inflow tightening measures. Moreover, the strongest inflow tightening actions respond more to mercantilist than to macroprudential concerns.

\subsection{Can additional proxies for mercantilist or macroprudential motivations improve the model fit?}

So far, the analysis has focused on a relatively simple model, with one proxy each of mercantilist and macroprudential motivations. That leads to the question of whether one can do better by adding proxies for each of the motivations. As discussed in section 3, recent literature specific to capital controls has recommended that capital controls be targeted to foreign borrowing, specifically foreign currency borrowing. Therefore, I tested a number of additional proxies for macroprudential motivations, sequentially adding them to the baseline model. The results are in Table 6 below. To ensure consistency across models, all the models in Table 6 are run on the same observations as the smallest available data series - in this case, 
equity prices - so the baseline model in this table is not the same as in Table 3. Table 6 shows that most of the additional variables are not significantly different from zero. Moreover, their contribution to the RPS, where they do decrease the RPS, is marginal, only in the $4^{\text {th }}$ or $5^{\text {th }}$ decimal place.

An interesting result in the table is that many of the measures of external vulnerability - for example, external credit and the stock of foreign currency debt securities - are negatively associated with the probability of tightening inflow controls. A closer look the data on domestic and external credit suggests an explanation: rather than use countercyclical capital controls to manage external vulnerabilities, as suggested by the recent literature, EMEs are using capital controls to manage the total flow of credit in the economy. The correlation between bank credit gap and external credit/GDP in the sample is negative and significant (0.2 for the 21 countries in sample, -0.12 for the 11 active countries). Figure 6 plots the two series for four major emerging economies. Keeping in mind that the periods 2006-07 and 2010-11 were periods of tightening of inflow controls in most EMEs, and that the post-2012 period has seen liberalization of inflow controls, one can see that the figures suggest that EMEs were tightening inflow controls when domestic credit was booming, but foreign credit was low. Further, the surge in foreign credit in EMEs since 2012, which has received a lot of policy attention, seems to be an intended consequence of policy rather than happening despite it.

These results underscore the importance of looking at what EMEs actually do, to inform the debate on what they should do. The evidence in this paper suggests that EMEs do not directly target levels of foreign or foreign currency debt to calibrate capital controls, but rather use the domestic bank credit gap as the predominant measure of systemic risk. They prevent domestic residents from borrowing abroad when domestic banks are lending at a brisk pace, but ease restrictions on foreign borrowing when domestic banks are saddled with NPL (for example, in the post-2012 world). The targeting of foreign credit when domestic credit is booming may simply reflect that regulators find it easier to target foreign credit rather than domestic credit, either because of lack of adequate domestic prudential tools or because of shortcomings of a domestic institutional framework where, for example, state banks dominate domestic lending and the domestic regulators can do little to stem overlending to politically preferred sectors.

In Table 7, I report the results for adding variables for mercantilist motivation. As there are only a few additional variables, I report the full regression results rather than just the summary. The additional variables, relative GDP growth or growth in manufacturing sector IIP, or export growth (value or volume) are also not significant and do not improve the baseline specification. 
Table 6: Additional macroprudential proxies are not significant and do not improve model predictions for inflow tightening baseline

\begin{tabular}{lccccc}
\hline & N & LL & RPS & Sign & Significant? \\
\hline Baseline & 6641 & -1579.7 & 0.06627 & & \\
Bank Credit/GDP, (yoy gr) & 6641 & -1579.5 & 0.06619 & - & No \\
Equity Prices (Trend Dev.) & 6641 & -1578.1 & 0.06638 & + & No \\
Equity Prices (yoy gr) & 6641 & -1578.9 & 0.06628 & + & No \\
External Credit/GDP (Trend Dev.) & 6641 & -1579.5 & 0.06621 & - & No \\
External Credit/GDP (yoy gr) & 6641 & -1579.5 & 0.06623 & + & No \\
External Credit/GDP, Non-Banks (Trend Dev.) & 6641 & -1579.6 & 0.06630 & - & No \\
External Credit/GDP, Non-Banks (yoy gr) & 6641 & -1577.9 & 0.06637 & - & No \\
External Debt Securities Net Flow (\% of GDP) & 6641 & -1578.4 & 0.06617 & - & No \\
External Debt Securities Stock (\% of GDP) & 6641 & -1579.4 & 0.06633 & - & No \\
Foreign Currency Debt Securities Stock (\% of GDP) & 6641 & -1579.4 & 0.06633 & - & No \\
Foreign Currency Debt Securities Stock (Trend Dev.) & 6641 & -1579.5 & 0.06624 & + & No \\
Foreign Currency Debt Securities, Net Flows & & & & & No \\
(\% of GDP) & 6641 & -1578.4 & 0.06618 & - & No \\
Other Investment Inflows (Trend Dev.) & 6641 & -1579.7 & 0.06628 & + & Now
\end{tabular}

Note: Dependent variable is the ordered weighted, non-FDI net inflow tightening measures. Estimation method is panel ordered logit, assuming random effects and using robust standard errors.

Figure 6: For many EMEs, external credit appears to substitute for bank credit
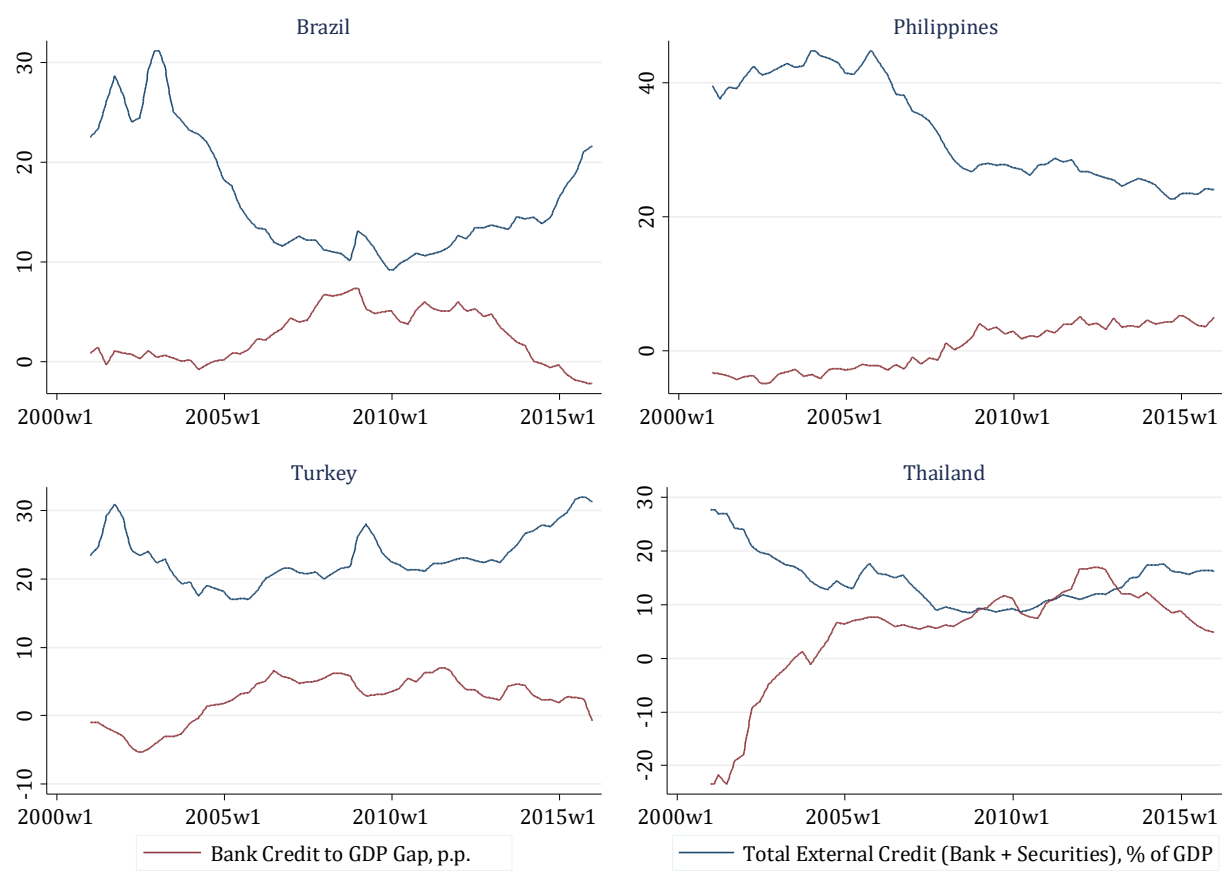
Table 7: Additional mercantilism proxies are not significant and do not improve model predictions for inflow tightening baseline

\begin{tabular}{|c|c|c|c|c|c|}
\hline & \multicolumn{5}{|c|}{ Dependent Variable: Weighted Net Inflow Tightenings (non-FDI) } \\
\hline & 1 & 2 & 3 & 4 & 5 \\
\hline Mercantilism Proxy (Country-Specific) & $1.39 * \star \star$ & $1.38^{* \star *}$ & $1.42^{\star \star \star}$ & $1.41^{\star \star \star}$ & $1.39^{\star \star *}$ \\
\hline Bank Credit-GDP Gap (\%) & $1.29^{\star \star}$ & $1.28^{\star *}$ & $1.31^{\star *}$ & $1.37^{\star \star \star}$ & $1.29 \star *$ \\
\hline Relative GDP Growth & 1.06 & & & & \\
\hline Manufacturing IIP Growth & & 1.09 & & & \\
\hline Relative Manufacturing IIP Growth & & & 0.96 & & \\
\hline Export Volume Growth (yoy, \%) & & & & 1.01 & \\
\hline Export Growth (yoy, \%) & & & & & 1.07 \\
\hline VIX & 0.99 & 0.99 & 0.99 & 0.98 & 0.99 \\
\hline Crisis Dummy & 0.39 & 0.38 & 0.4 & 0.36 & 0.38 \\
\hline Previous Policy Action (T, E) & $1.29 * \star \star$ & $1.29 * * *$ & $1.31^{\star \star \star}$ & $1.31^{\star *}$ & $1.31^{* \star *}$ \\
\hline Fiscal Stance & $1.16^{\star \star}$ & $1.15^{\star \star}$ & $1.16^{\star \star}$ & $1.14^{\star}$ & $1.14^{\star}$ \\
\hline Monetary Stance & 0.86 & 0.86 & 0.88 & 0.91 & 0.86 \\
\hline Observations & 6641 & 6634 & 6634 & 4936 & 6641 \\
\hline Number of Countries & 11 & 11 & 11 & 9 & 11 \\
\hline Pseudo-Log Likelihood & -1579 & -1579 & -1579 & -1285 & -1579 \\
\hline Chi-Squared (All Coefficients $=0$ ) & 96.14 & 88.57 & 89.77 & 325.5 & 81.86 \\
\hline P-value (Chi-Squared) & 0 & 0 & 0 & 0 & 0 \\
\hline
\end{tabular}

Notes: Reported values are proportional odds ratios. Sample period is 2001w1-2015q52. All domestic control variables are one-week lagged. All continuous domestic variables are standardized but centred at 0 , i.e., the variables are divided by their standard deviation but not demeaned. Monetary policy stance and fiscal policy stance are variables that take the value +1 if monetary policy is tightened in the previous week (or structural balance improves), -1 for expansionary policies and 0 otherwise. Robust standard errors used. ${ }^{* * *} p<0.01,{ }^{* *} p<0.05,{ }^{*} p<0.10$

\subsection{Predicting net NKI restricting actions}

The analysis so far has examined the motivations for changing controls on capital inflows. Yet, countries have another tool to resist exchange rate appreciations: the easing of outflow restrictions (Aizenman and Pasricha, 2013). In this section, I analyze the motivations for changing net NKI restricting actions, defined as the sum of net inflow tightening actions and net outflow easing actions per week. These actions respond systematically only to mercantilist concerns (Table 8 and Figure 7). The size and significance of the estimated proportional odds ratios for mercantilism proxies is similar to those in Table 3 for net inflow tightening actions. Increases in the credit-to-GDP gap increase the odds of a strong net NKI restricting action over the odds of the alternatives, but the coefficient is not significant at the average values of other variables.

The results of Table 8 and Table 3 together imply that countries use both inflow tightening and outflow easing actions to respond systematically to mercantilist concerns, but use only inflow tightening actions to respond to macroprudential concerns. This is further evidence that policy is carefully calibrated: outflow easings do not directly reduce systemic risk, but can mitigate exchange rate pressures. 
Table 8: Net NKI restricting actions respond only to mercantilist concerns

\begin{tabular}{|c|c|c|c|c|c|c|}
\hline & \multicolumn{6}{|c|}{ Dependent Variable: Weighted Net NKI Restrictions (non-FDI) } \\
\hline & 1 & 2 & 3 & 4 & 5 & 6 \\
\hline Mercantilism Proxy (Country-Specific) & $1.34^{\star \star \star}$ & & & & & \\
\hline Mercantilism Proxy (Nominal, 13-wk appr., \%) & & $1.26^{\star *}$ & & & & \\
\hline Mercantilism Proxy (Real, 13-wk appr., \%) & & & $1.24^{\star \star}$ & & & \\
\hline Mercantilism Proxy (Nominal, yoy appr., \%) & & & & $1.26^{\star \star \star}$ & & \\
\hline Mercantilism Proxy (Real, yoy appr., \%) & & & & & $1.23^{\star \star}$ & \\
\hline $\begin{array}{l}\text { Exchange Rate vs. USD (Nominal, } \\
\text { 13-wk appr., \%) }\end{array}$ & & & & & & $1.65^{\star \star \star}$ \\
\hline Bank Credit-GDP Gap (\%) & 1.16 & 1.16 & 1.16 & 1.15 & 1.16 & 1.15 \\
\hline Previous Policy Action (T, E) & 1.11 & 1.12 & 1.12 & $1.12^{*}$ & 1.12 & $1.11^{*}$ \\
\hline Fiscal Stance & 1.09 & 1.08 & 1.08 & 1.08 & 1.08 & 1.08 \\
\hline Monetary Stance & $0.81^{\star \star \star}$ & $0.82^{\star \star \star}$ & $0.82^{\star \star \star}$ & $0.82^{\star *}$ & $0.81^{* \star *}$ & 0.87 \\
\hline VIX & 0.99 & 0.99 & 0.99 & 0.99 & 0.99 & 0.99 \\
\hline Crisis Dummy & $0.43^{\star}$ & $0.38^{* *}$ & $0.38^{\star \star}$ & $0.39 *$ & $0.39 *$ & 0.81 \\
\hline Observations & 8,855 & 8,855 & 8,855 & 8,855 & 8,855 & 8,855 \\
\hline Number of Countries & 13 & 13 & 13 & 13 & 13 & 13 \\
\hline Pseudo-Log Likelihood & -1927 & -1932 & -1933 & -1932 & -1933 & -1902 \\
\hline Chi-Squared (All Coefficients =0) & 171.1 & 118.8 & 153 & 66.87 & 111.1 & 259.7 \\
\hline P-value (Chi-Squared) & 0 & 0 & 0 & 0 & 0 & 0 \\
\hline
\end{tabular}

Notes: Reported values are proportional odds ratios. Sample period is 2001w1-2015q52. All domestic control variables are oneweek lagged. All continuous domestic variables are standardized but centred at 0 , i.e., the variables are divided by their standard deviation but not demeaned. Monetary policy stance and fiscal policy stance are variables that take the value +1 if monetary policy is tightened in the previous week (or structural balance improves), -1 for expansionary policies and 0 otherwise. Robust standard errors used. ${ }^{* *} p<0.01,{ }^{* *} p<0.05,{ }^{*} p<0.10$

Figure 7: Net NKI restricting measures respond strongly to appreciation pressures against US dollar

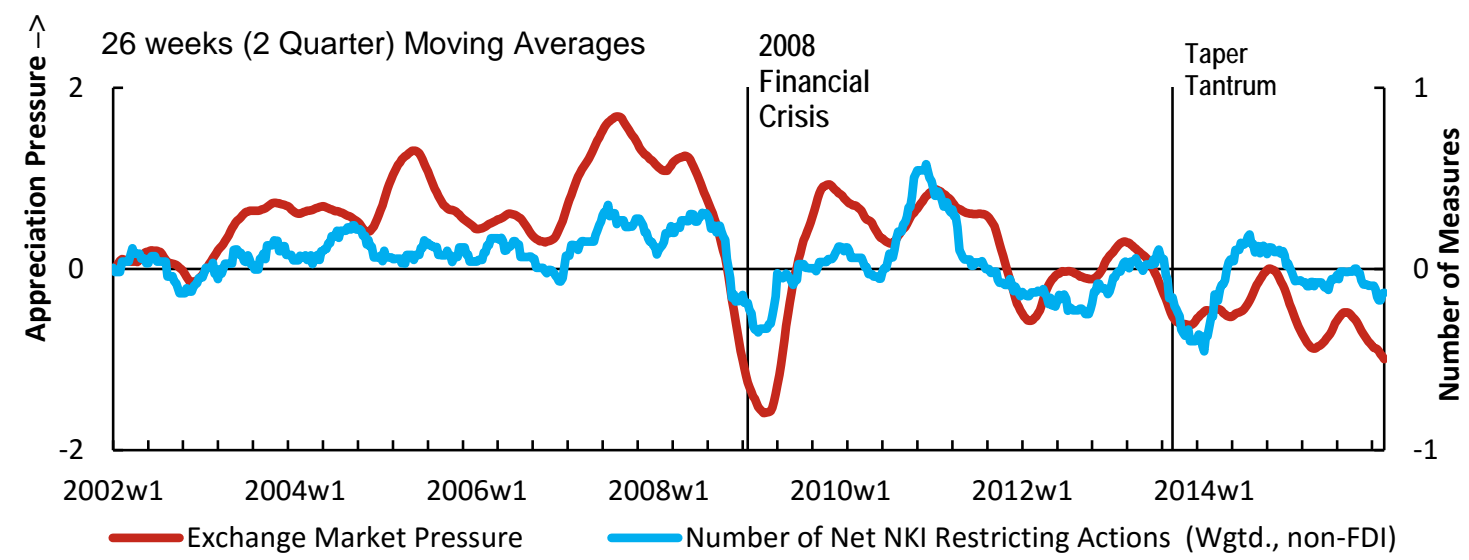

Last observation: 2015w52

Note: Exchange market pressure index is the EME average. Each emerging market's EMP is computed as the sum of standardized appreciation in nominal exchange rate against US dollar and standardized percentage increase in foreign exchange reserves excluding gold. The reserves series is interpolated from quarterly data before computing percentage changes. Net NKI Restricting actions are computed as (Inflow Tightenings - Inflow Easings) + (Outflow Easings - Outflow Tightenings). The measures are weighted and exclude those related to FDI but include currency-based measures.

Source: IMF International Financial Statistics, Datastream and Author's calculations 


\subsection{Understanding the results - What drives the weights on mercantilist and macroprudential motivations?}

So far the results suggest that both macroprudential and mercantilist motivations are important in determining the systematic calibration of capital controls. If, from an international policy coordination perspective, it is important that capital controls should respond only to macroprudential concerns, then we need to understand if there are any structural factors that drive the relative weight of the two motivations in the policy reaction function. In this section, I explore two such factors: the degree of sensitivity of a country's export prices to exchange rate changes, and the domestic governance frameworks for macroprudential policies. Specifically, I ask two questions: First, do countries with high export price exchange rate pass-though (ERPT) respond more to mercantilist motivations? Second, has the development of governance arrangements for macroprudential policies led to capital controls being used in a more macroprudential fashion?

High ERPT to export prices means that the exporter's trading partners bear more of the cost of the exporting country's currency appreciation. This means that the countries' exports are potentially more sensitive to that appreciation, and policy-makers may in turn respond more to stem such appreciation. I use a dummy variable, which equals 1 for countries with greater than median export price ERPT and baseline specification for net NKI restricting actions (Table 8, column 1). I use the baseline for net NKI restricting measures because earlier I found evidence that both inflow tightening and outflow easing are used to respond to mercantilist motivations. I use Bussière, Gaulier and Steingress's (2016) baseline (no fixed effects) estimates of export price elasticities to construct the dummy variable. The results of the regressions are in Table 9 below. The interaction term is significant and suggests that at the average value of all variables, higher ERPT countries are more responsive to appreciation of the currency against trade competitors. As the model is non-linear, the size and significance of the interaction term depends on the values of the other variables. Therefore, to illustrate the effect of high ERPT, in Figure 8, I compute the predicted probability of taking no net NKI restricting action, for different values of mercantilism proxy, for high and low ERPT countries. The figure shows that for a wide range of values of country-specific mercantilism proxy, countries with high ERPT to export prices respond more strongly to competitiveness changes against trade competitors than low ERPT countries do.

To explore the issue of whether improvement in governance arrangements increases the weight on macroprudential motivations, I interact the bank credit gap variable with a dummy that equals 1 after the date on which each country enhanced its governance arrangements for macroprudential policies. These dates are listed in Table A.1 in the Appendix. The results of the regressions are in Table 10 below. Net inflow tightening actions were countercyclical to bank credit gap in the period before the enhancement of governance arrangements for macroprudential policies, but after the introduction of governance arrangements became even more countercyclical. This can be seen in Figure 9, which plots the 
predicted probabilities of taking no action, at different values of bank credit gap (with other variables held at their mean values), for the regression specification in Table 10, equation 1.

These results give a positive message: that development of governance frameworks can enhance the macroprudential use of capital controls. But they also caution that in countries that stand to lose more from exchange rate appreciation, it may never be possible to have capital controls used only in a macroprudential manner.

Table 9: Exploring mercantilist motivations in net NKI restricting actions

\begin{tabular}{|c|c|c|c|c|c|}
\hline & \multicolumn{5}{|c|}{$\begin{array}{c}\text { Dependent Variable: Weighted Net NKI Restrictions } \\
\text { (non-FDI) }\end{array}$} \\
\hline & (1) & (2) & (3) & (4) & (5) \\
\hline Mercantilism Proxy (Country-Specific) & $1.14^{\star *}$ & & & & \\
\hline $\begin{array}{l}\text { Mercantilism Proxy (Country-Specific) * } \\
\text { [Dummy, High ERPT] }\end{array}$ & $1.40^{\star \star}$ & & & & \\
\hline Mercantilism Proxy (Nominal, 13-wk appr., \%) & & $1.09^{\star}$ & & & \\
\hline $\begin{array}{l}\text { Mercantilism Proxy (Nominal, 13-wk appr., \%) * } \\
\text { [Dummy, High ERPT] }\end{array}$ & & $1.34^{*}$ & & & \\
\hline Mercantilism Proxy (Real, 13-wk appr., \%) & & & 1.08 & & \\
\hline $\begin{array}{l}\text { Mercantilism Proxy (Real, 13-wk appr., \%) * } \\
\text { [Dummy, High ERPT] }\end{array}$ & & & 1.31 & & \\
\hline Mercantilism Proxy (Nominal, yoy appr., \%) & & & & $1.11^{*}$ & \\
\hline $\begin{array}{l}\text { Mercantilism Proxy (Nominal, yoy appr., \%) * } \\
\text { [Dummy, High ERPT] }\end{array}$ & & & & $1.32^{\star}$ & \\
\hline Mercantilism Proxy (Real, yoy appr., \%) & & & & & 1.11 \\
\hline $\begin{array}{l}\text { Mercantilism Proxy (Real, yoy appr., \%) * } \\
\text { [Dummy, High ERPT] }\end{array}$ & & & & & 1.22 \\
\hline Dummy, High ERPT & $0.59^{*}$ & 0.58 & 0.61 & $0.56^{\star}$ & 0.61 \\
\hline Bank Credit-GDP Gap (\%) & 1.14 & 1.15 & 1.16 & 1.13 & 1.16 \\
\hline Previous Policy Action (T, E) & 1.09 & 1.11 & 1.1 & 1.11 & 1.1 \\
\hline Fiscal Stance & 1.11 & 1.09 & 1.09 & 1.1 & 1.1 \\
\hline Monetary Stance & $0.82^{\star *}$ & $0.84^{* \star}$ & $0.83^{\star \star \star}$ & $0.83^{\star \star}$ & $0.82^{\star \star}$ \\
\hline VIX & 0.99 & 0.99 & 0.99 & 0.99 & 0.99 \\
\hline Crisis Dummy & $0.44^{\star}$ & $0.36^{\star \star}$ & $0.37^{\star \star}$ & $0.39 *$ & $0.40^{*}$ \\
\hline Observations & 8855 & 8855 & 8855 & 8855 & 8855 \\
\hline Number of Countries & 13 & 13 & 13 & 13 & 13 \\
\hline Pseudo-Log Likelihood & -1922 & -1928 & -1929 & -1928 & -1931 \\
\hline Chi-Squared (All Coefficients $=0$ ) & 906.9 & 260.8 & 352.4 & 148.9 & 224.2 \\
\hline P-value (Chi-Squared) & 0 & 0 & 0 & 0 & 0 \\
\hline
\end{tabular}

Notes: Reported values are proportional odds ratios. Sample period is 2001w1-2015q52. All domestic control variables are oneweek lagged. All continuous domestic variables are standardized but centred at 0 , i.e., the variables are divided by their standard deviation but not demeaned. Monetary policy stance and fiscal policy stance are variables that take the value +1 if monetary policy is tightened in the previous week (or structural balance improves), -1 for expansionary policies and 0 otherwise. Robust standard errors used. ${ }^{* *} p<0.01,{ }^{* *} p<0.05,{ }^{*} p<0.10$ 
Table 10: Exploring macroprudential motivations in net inflow tightening actions

\begin{tabular}{|c|c|c|c|c|c|}
\hline & \multicolumn{5}{|c|}{ Dependent Variable: Weighted Net Inflow Tightening (non-FDI) } \\
\hline & $(1)$ & $(2)$ & (3) & $(4)$ & (5) \\
\hline Mercantilism Proxy (Country-Specific) & $1.32^{\star \star *}$ & & & & \\
\hline Mercantilism Proxy (Nominal, 13-wk appr., \%) & & 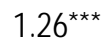 & & & \\
\hline Mercantilism Proxy (Real, 13-wk appr., \%) & & & $1.25^{\star \star \star}$ & & \\
\hline Mercantilism Proxy (Nominal, yoy appr., \%) & & & & $1.27^{\star \star \star}$ & \\
\hline Mercantilism Proxy (Real, yoy appr., \%) & & & & & $1.25^{\star \star \star}$ \\
\hline Bank Credit-GDP Gap (\%) & $1.19 * \star *$ & 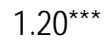 & $1.20 * \star \star$ & $1.16^{\star \star \star}$ & $1.18^{\star \star \star}$ \\
\hline $\begin{array}{l}\text { Bank Credit-GDP Gap (\%) * } \\
\text { [Dummy, Post-Governance] }\end{array}$ & $1.19 *$ & $1.19 *$ & $1.19 *$ & $1.23^{*}$ & $1.24^{\star \star}$ \\
\hline Dummy, Post-Governance & 0.79 & 0.77 & 0.75 & 0.77 & 0.73 \\
\hline Previous Policy Action (T, E) & $1.33^{\star * *}$ & $1.34^{\star * *}$ & $1.33^{* * *}$ & $1.33^{\star * *}$ & $1.33^{\star \star \star}$ \\
\hline Fiscal Stance & $1.14^{\star \star}$ & $1.13^{\star \star}$ & $1.13^{\star \star}$ & $1.13^{\star *}$ & $1.13^{\star \star}$ \\
\hline Monetary Stance & $0.86^{*}$ & 0.89 & 0.89 & 0.87 & 0.87 \\
\hline VIX & 0.99 & 0.99 & 0.99 & 0.99 & 0.99 \\
\hline Crisis Dummy & $0.32^{*}$ & $0.28^{\star \star}$ & $0.27^{\star \star}$ & $0.30 *$ & $0.29 *$ \\
\hline Observations & 7448 & 7448 & 7448 & 7448 & 7448 \\
\hline Number of Countries & 11 & 11 & 11 & 11 & 11 \\
\hline Pseudo-Log Likelihood & -1710 & -1713 & -1713 & -1713 & -1713 \\
\hline Chi-Squared (All Coefficients $=0$ ) & 327.1 & 556.2 & 338.6 & 1182 & 403.6 \\
\hline P-value (Chi-Squared) & 0 & 0 & 0 & 0 & 0 \\
\hline
\end{tabular}

Notes: Reported values are proportional odds ratios. Sample period is 2001w1-2015q52. All domestic control variables are oneweek lagged. All continuous domestic variables are standardized but centred at 0 , i.e., the variables are divided by their standard deviation but not demeaned. Monetary policy stance and fiscal policy stance are variables that take the value +1 if monetary policy is tightened in the previous week (or structural balance improves), -1 for expansionary policies and 0 otherwise. Robust standard errors used. ${ }^{* * \star} p<0.01,{ }^{* \star} p<0.05,{ }^{*} p<0.10$

Figure 8: Countries with high exchange rate pass-through to export prices respond more to mercantilist concerns

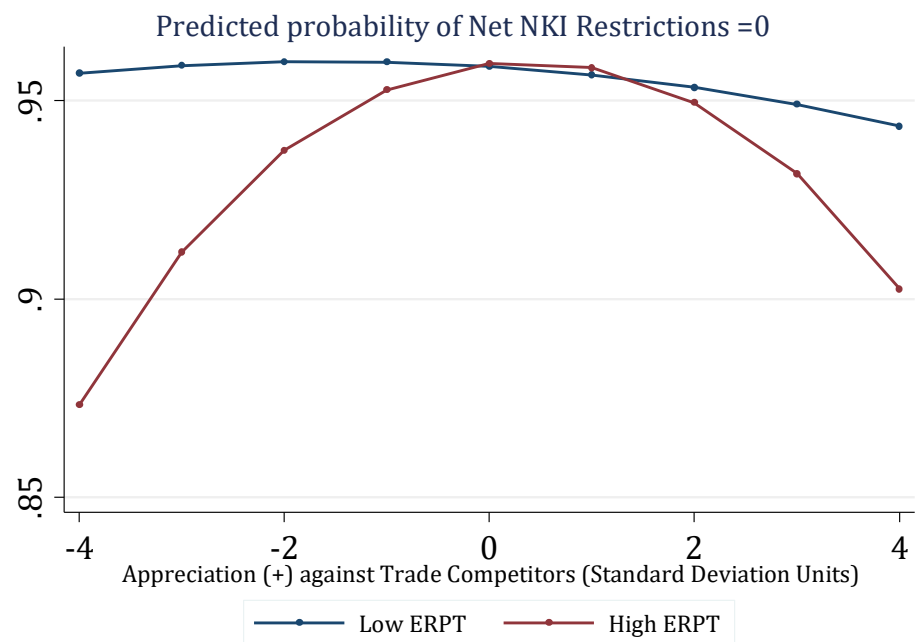

Notes: The graphs plot the predicted probabilities of taking no net NKI restricting actions (inflow tightening + outflow easing actions) against values of country-specific mercantilism proxy (measured in standard deviation units). The specification used is Table 8, model 1. All other variables are held at their mean values. 
Figure 9: Stronger governance arrangements for macroprudential policies meant more responsiveness of inflow controls to domestic bank credit gap

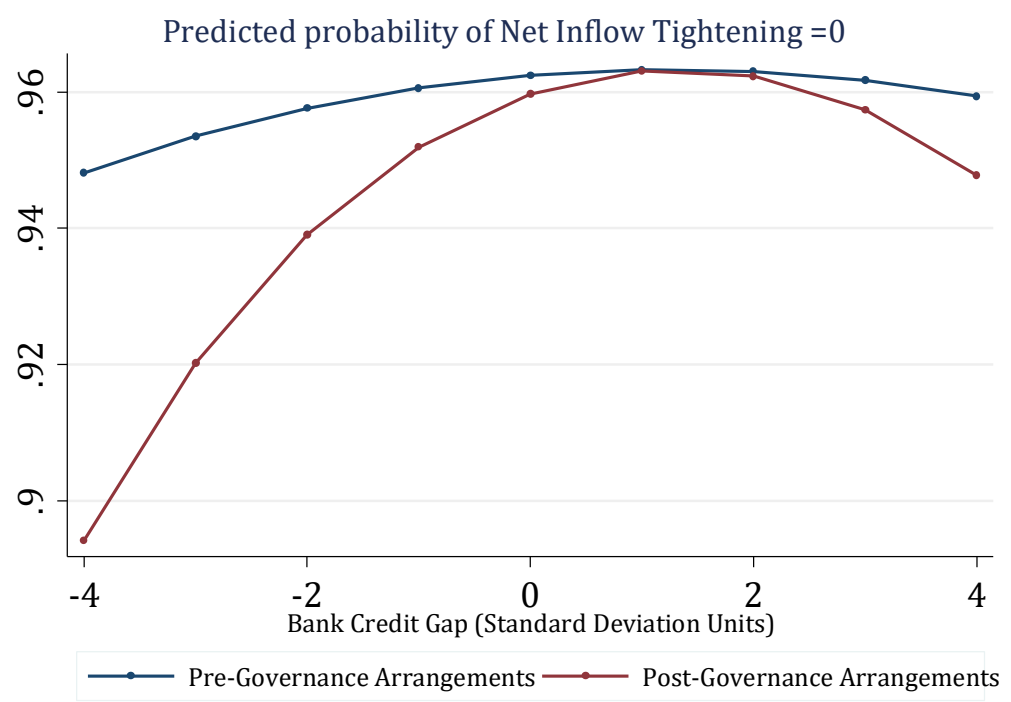

Note: The graph summarizes the marginal effects of the post-governance arrangements-time dummy in a model predicting non-FDI weighted net inflow tightening measures (Table 10, model 1). All other variables are held at their mean values.

\section{Robustness checks}

The results presented above are robust to a number of alterations in specifications. First, I use alternative measures of capital controls policy (Table 11). I run the baseline specifications without reducing the number of ordered categories. This leads to estimation of a large number of cut-offs for the latent variable, but doesn't affect the sign or significance (or the approximate size) of the estimated coefficients. The results presented in section 5 are also robust to using unweighted policy actions. Estimating reaction functions on all changes, including those affecting FDI, leads to a small decline in the estimated coefficient on bank credit gap in the baseline regression explaining net inflow tightening actions, but the coefficient is still significant. The other results are robust to including FDI-related changes.

Second, I include all countries in sample, not only the active ones. This reduces the estimated size of both coefficients (on mercantilist and macroprudential motivations), but the effects are still significant (Table 11, column 4).

Third, I control for other domestic variables, including reserves accumulation, domestic macroprudential policy actions from Cerutti et al. (2016) and CPI inflation (Table 12). The baseline results are robust to adding these variables. I also replace the monetary and fiscal policy stance variables with actual policy changes.

Fourth, I use alternative measures of global liquidity instead of VIX, including global bank claims (as percentage of global GDP, from BIS) and US federal funds shadow rate (Table 
13). I also add several key variables in the same specification. These modifications do not change the baseline results.

Finally, I report the goodness of fit test of out-of-sample forecasts (Table 14). I use the last three years of the sample (2012-2015) as the out-of-sample period. Table 14 tests the significance of AUROC differences between the out-of-sample forecasts of the same four models as in Table 5, i.e., Baseline, VIX-only, FX-only and MP-only models. The out-of-sample forecast performance of the models is a bit worse than the in-sample forecast performance, but the relative performance of the different models is in line with their relative in-sample performance.

Table 11: Robustness checks: net inflow tightening actions

\begin{tabular}{|c|c|c|c|c|}
\hline \multirow{3}{*}{ Sample } & (1) & (2) & (3) & \multirow{3}{*}{$\begin{array}{r}\text { (4) } \\
\text { All Countries } \\
\\
\text { Ordered, } \\
\text { Weighted } \\
\text { non-FDI } \\
\text { actions }\end{array}$} \\
\hline & \multicolumn{3}{|c|}{ Active Countries } & \\
\hline & $\begin{array}{c}\text { Unordered, } \\
\text { Weighted, } \\
\text { non-FDI actions }\end{array}$ & $\begin{array}{c}\text { Ordered, } \\
\text { Unweighted, } \\
\text { non-FDI } \\
\text { actions }\end{array}$ & $\begin{array}{c}\text { Ordered, } \\
\text { Unweighted, } \\
\text { including } \\
\text { FDl-related } \\
\text { actions }\end{array}$ & \\
\hline $\begin{array}{l}\text { Mercantilism Proxy } \\
\text { (Country-Specific) }\end{array}$ & $1.33^{\star \star \star}$ & $1.29 * \star \star$ & 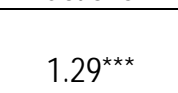 & $1.21 * *$ \\
\hline Bank Credit-GDP Gap (\%) & $1.29 * \star \star$ & $1.27^{\star \star}$ & $1.19 *$ & $1.26 * \star \star$ \\
\hline Previous policy action (T, E) & $1.32^{\star \star *}$ & $1.32^{* * *}$ & $1.25^{\star \star *}$ & $1.39 * \star \star$ \\
\hline Fiscal Stance & $1.16^{\star \star \star}$ & $1.15^{\star \star}$ & $1.14^{\star \star *}$ & $1.16^{\star \star \star}$ \\
\hline Monetary Stance & $0.86^{*}$ & 0.88 & $0.84^{\star *}$ & 0.91 \\
\hline VIX & 0.99 & 0.99 & 1.00 & 0.99 \\
\hline Crisis Dummy & $0.32^{*}$ & $0.29 \star \star$ & $0.34^{\star *}$ & $0.31^{*}$ \\
\hline Observations & 7,448 & 7,448 & 7,640 & 13,442 \\
\hline Number of Countries & 11 & 11 & 11 & 19 \\
\hline Pseudo-Log Likelihood & -3072 & -1635 & -1881 & -2105 \\
\hline Chi-Squared (All Coefficients $=0$ ) & 75.89 & 67.62 & 1596 & 57.78 \\
\hline P-value (Chi-Squared) & 0 & 0 & 0 & $4.18 \mathrm{e}-10$ \\
\hline
\end{tabular}

Notes: Reported values are proportional odds ratios. Sample period is 2001w1-2015q52. All domestic control variables are oneweek lagged. All continuous domestic variables are standardized but centred at 0 , i.e., the variables are divided by their standard deviation but not demeaned. Robust standard errors used. ${ }^{* \star *} p<0.01,{ }^{* *} p<0.05,{ }^{*} p<0.10$ 
Table 12: Robustness checks: adding other domestic macroeconomic and policy variables

Dependent Variable: Ordered, Weighted Net Inflow Tightening Actions (non-FDI)

\begin{tabular}{|c|c|c|c|c|c|}
\hline & (1) & $(2)$ & (3) & (4) & (5) \\
\hline Mercantilism Proxy (Country-Specific) & $1.33^{\star \star \star}$ & $1.32^{\star \star \star}$ & $1.33^{\star \star \star}$ & $1.24^{\star \star}$ & $1.25^{\star}$ \\
\hline Bank Credit-GDP Gap (\%) & $1.26^{\star \star \star}$ & $1.22^{\star \star}$ & $1.28 * \star \star$ & $1.23^{\star \star \star}$ & $1.24^{\star \star *}$ \\
\hline External Credit (\% of GDP) & & & & 0.97 & \\
\hline External Debt Securities Stock (\% of GDP) & & & & & 1.00 \\
\hline Previous Policy Action (T, E) & $1.32^{\star \star \star}$ & $1.32^{\star \star *}$ & $1.33^{\star \star *}$ & $1.30^{\star * \star}$ & $1.29 * \star \star$ \\
\hline Fiscal Stance & $1.16^{\star \star \star}$ & $1.16^{\star \star \star}$ & $1.16^{\star \star \star}$ & $1.15^{\star \star}$ & $1.15^{\star \star}$ \\
\hline Monetary Stance & 0.88 & 0.88 & 0.90 & $0.80^{\star *}$ & $0.80^{\star *}$ \\
\hline Federal Funds Shadow Rate (\%) & 1.01 & & & & \\
\hline Global Bank Claims ( $\%$ of GDP) & & 1.02 & & & \\
\hline Oil Prices (WTI, Avg. \$ per Barrel) & & & 1.00 & & \\
\hline Domestic Macroprudential Policies (>0 =Tightening) & & & & 1.06 & 1.06 \\
\hline Reserves Accumulation (\% of GDP) & & & & $1.33^{\star \star *}$ & $1.34^{\star \star *}$ \\
\hline VIX & & & & 1.00 & 1.00 \\
\hline Crisis Dummy & $0.22^{\star \star \star}$ & $0.21^{\star \star \star}$ & 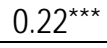 & 0.44 & 0.43 \\
\hline Observations & 7,448 & 7,448 & 7,448 & 6,887 & 6,887 \\
\hline Number of Countries & 11 & 11 & 11 & 11 & 11 \\
\hline Pseudo-Log Likelihood & -1713 & -1712 & -1713 & -1609 & -1609 \\
\hline Chi-Squared (All Coefficients $=0$ ) & 68.27 & 64.87 & 71.02 & 2319 & 6504 \\
\hline P-value (Chi-Squared) & 0 & 0 & 0 & 0 & 0 \\
\hline
\end{tabular}

Notes: Reported values are proportional odds ratios. Sample period is 2001w1-2015q52. All domestic control variables are oneweek lagged. All continuous domestic variables are standardized but centred at 0 , i.e., the variables are divided by their standard deviation but not demeaned. Robust standard errors used. ${ }^{* \star *} p<0.01,{ }^{* \star} p<0.05,{ }^{*} p<0.10$ 
Table 13: Robustness checks: alternative global variables and adding several controls together

\begin{tabular}{lcccc}
\hline & $(1)$ & $(2)$ & $(3)$ & $(4)$ \\
\hline Mercantilism Proxy (Country-Specific) & $1.33^{\star \star \star}$ & $1.32^{\star \star \star}$ & $1.24^{\star \star}$ & $1.25^{\star}$ \\
Bank Credit-GDP Gap (\%) & $1.26^{\star \star \star}$ & $1.22^{\star \star}$ & $1.23^{\star \star \star}$ & $1.24^{\star \star \star}$ \\
External Credit (\% of GDP) & & & 0.97 & \\
External Debt Securities Stock (\% of GDP) & & & & 1.00 \\
Previous Policy Action (T, E) & $1.32^{\star \star \star}$ & $1.32^{\star \star \star}$ & $1.30^{\star \star \star}$ & $1.29^{\star \star \star}$ \\
Fiscal Stance & $1.16^{\star \star \star}$ & $1.16^{\star \star \star}$ & $1.15^{\star \star}$ & $1.15^{\star \star}$ \\
Monetary Stance & 0.88 & 0.88 & $0.80^{\star \star}$ & $0.80^{\star \star}$ \\
Federal Funds Shadow Rate (\%) & 1.01 & & & \\
Global Bank Claims (\% of GDP) & & 1.02 & & \\
VIX & & & 1.00 & 1.00 \\
Crisis Dummy & $0.22^{\star \star \star}$ & $0.21^{\star \star \star}$ & 0.44 & 0.43 \\
Domestic Macroprudential Policies (>0 = Tightening) & & & 1.06 & 1.06 \\
Reserves Accumulation (\% of GDP) & & & $1.33^{\star \star \star}$ & $1.34^{\star \star \star}$ \\
\hline Observations & 7,448 & 7,448 & 6,887 & 6,887 \\
Number of Countries & 11 & 11 & 11 & 11 \\
Pseudo-Log Likelihood & -1713 & -1712 & -1609 & -1609 \\
Chi-Squared (All Coefficients =0) & 68.27 & 64.87 & 2319 & 6504 \\
P-value (Chi-Squared) & 0 & 0 & 0 & 0 \\
\hline Nos & & & 0 & \\
\hline
\end{tabular}

Notes: Reported values are proportional odds ratios. Sample period is 2001w1-2015q52. All domestic control variables are oneweek lagged. All continuous domestic variables are standardized but centred at 0 , i.e., the variables are divided by their standard deviation but not demeaned. Monetary policy stance and fiscal policy stance are variables that take the value +1 if monetary policy is tightened in the previous week (or structural balance improves), -1 for expansionary policies and 0 otherwise. Robust standard errors used. ${ }^{* *} p<0.01,{ }^{* *} p<0.05,{ }^{*} p<0.10$ 
Table 14: Robustness checks: out-of-sample forecasts

\begin{tabular}{|c|c|c|c|c|c|c|c|}
\hline & $\mathrm{N}$ & AUROC & Std. Err. & \multicolumn{2}{|c|}{ [95\% Conf. Interval] } & $x^{2}$ & p-value \\
\hline \multicolumn{8}{|c|}{ Ordered (Weighted, non-FDI) Net Inflow Tightening = -1 } \\
\hline Baseline & 2288 & 0.79 & 0.04 & 0.7 & 0.87 & . & \\
\hline VIX-Only & 2288 & 0.67 & 0.04 & 0.59 & 0.75 & 3.56 & 0.06 \\
\hline FX-Only & 2288 & 0.74 & 0.04 & 0.66 & 0.82 & 4.87 & 0.03 \\
\hline MP-Only & 2288 & 0.78 & 0.05 & 0.69 & 0.87 & 0.74 & 0.39 \\
\hline \multicolumn{8}{|c|}{ Ordered (Weighted, non-FDI) Net Inflow Tightening = -0.5} \\
\hline Baseline & 2288 & 0.64 & 0.04 & 0.56 & 0.72 & . & \\
\hline VIX-Only & 2288 & 0.42 & 0.04 & 0.35 & 0.49 & 13.8 & 0 \\
\hline FX-Only & 2288 & 0.58 & 0.04 & 0.51 & 0.66 & 2.54 & 0.11 \\
\hline MP-Only & 2288 & 0.71 & 0.04 & 0.63 & 0.78 & 7.83 & 0.01 \\
\hline \multicolumn{8}{|c|}{ Ordered (Weighted, non-FDI) Net Inflow Tightening = 0} \\
\hline Baseline & 2288 & 0.47 & 0.03 & 0.42 & 0.52 & . & \\
\hline VIX-Only & 2288 & 0.61 & 0.03 & 0.56 & 0.66 & 8.04 & 0 \\
\hline FX-Only & 2288 & 0.42 & 0.03 & 0.36 & 0.47 & 6.65 & 0.01 \\
\hline MP-Only & 2288 & 0.47 & 0.03 & 0.42 & 0.52 & 0 & 0.97 \\
\hline \multicolumn{8}{|c|}{ Ordered (Weighted, non-FDI) Net Inflow Tightening = 0.5} \\
\hline Baseline & 2288 & 0.62 & 0.06 & 0.5 & 0.75 & . & \\
\hline VIX-Only & 2288 & 0.62 & 0.06 & 0.5 & 0.73 & 0.02 & 0.88 \\
\hline FX-Only & 2288 & 0.54 & 0.06 & 0.43 & 0.65 & 3.49 & 0.06 \\
\hline MP-Only & 2288 & 0.64 & 0.06 & 0.51 & 0.76 & 0.18 & 0.67 \\
\hline \multicolumn{8}{|c|}{ Ordered (Weighted, non-FDI) Net Inflow Tightening = 1} \\
\hline Baseline & 2288 & 0.58 & 0.07 & 0.44 & 0.71 & & \\
\hline VIX-Only & 2288 & 0.52 & 0.08 & 0.37 & 0.67 & 0.26 & 0.61 \\
\hline FX-Only & 2288 & 0.58 & 0.07 & 0.44 & 0.71 & 10.92 & 0 \\
\hline MP-Only & 2288 & 0.56 & 0.06 & 0.44 & 0.68 & 0.96 & 0.33 \\
\hline
\end{tabular}

Note: In-sample period is 2001w1-2011q52, and out-of-sample period is 2012w1-2015w52. Each model is panel logit, with dependent variable redefined to be a dichotomous variable. For example, in the first block of models, the dependent variable takes value 1 when the ordered (weighted, non-FDI) net inflow tightening variable $=-1$, and 0 otherwise.

\section{Conclusions}

Are capital controls macroprudential or mercantilist? The results in this paper strongly suggest that they are both. The results provide clear evidence that capital controls policy in emerging markets has been systematic, and that it has responded to both macroprudential and mercantilist motivations. The use of net inflow tightening measures can be described by a function of mercantilist and macroprudential motivations. Moreover, the choice of instruments is also systematic: policy-makers respond to mercantilist concerns by using both instruments — inflow tightening and outflow easing. However, they use only inflow tightening in response to macroprudential concerns. This is the first paper to provide evidence of the existence of a macroprudential motivation in the use of capital controls policy, even before these controls were generally acknowledged as valid tools of the macroprudential policy toolkit. Yet, the analysis in this paper also underlines that the concerns of those who worry about a currency war are also justified - capital controls have also been systematically used to preserve competitive advantage in trade. 
These results highlight an assignment problem of using one tool (inflow controls) to meet multiple objectives (Tinbergen, 1962). They suggest a need for further debate on whether it would be globally optimal if countries used capital control actions solely as a tool of macroprudential policies, and if so, how to ensure that this is the case. The results also provide a potential answer to this second question - stronger governance frameworks for macroprudential policy. The evidence presented suggests that governance arrangements matter. Better understanding of policy objectives and tools, at the national and international levels, and better governance arrangements lead to more predictable policy. One caveat to the interpretation of the results is that much of the evidence on governance arrangements comes from the post-crisis period of ample global liquidity and it is difficult to disentangle the two effects.

The results also suggest that capital controls have not been targeted specifically to foreign-to-foreign currency debt. I find that inflow controls are not countercyclical to the specific macroprudential concerns related to external or foreign currency borrowing. Rather, policy appears acyclical to these variables, but is countercyclical to domestic bank credit to the private non-financial sector. The tightening of controls on foreign credit when domestic credit is booming may simply reflect that regulators find it easier to target foreign credit than domestic credit, either because of lack of adequate domestic prudential tools or because of shortcomings of domestic institutional frameworks. As capital controls become more widely used as tools of macroprudential policies, future research and policy discussions could focus on how best to ensure that these instruments are targeted directly to the vulnerabilities they seek to address. 


\section{References}

Aizenman, J and J Lee (2007) "International reserves: precautionary versus mercantilist views, theory and evidence", Open Economies Review, vol. 18, no. 2, pp 191-214.

Aizenman, J and G Pasricha (2013) "Why do emerging markets liberalize capital outflow controls? Fiscal versus net capital flow concerns", Journal of International Money and Finance, vol. 39, pp 28-64.

Alfaro, L, A Chari and F Kanczuk (2014) "The real effects of capital control taxes: firm-level evidence from a policy experiment", NBER Working Paper Series, no. 20726, December.

Avdjiev, S, L Gambacorta, L Goldberg and S Schiaffi (2017) "The shifting drivers of global liquidity", Bank for International Settlements, Working paper no. 644, June.

Basu, K, B Eichengreen and P Gupta (2014) "From tapering to tightening: The impact of the Fed's exit on India", World Bank Policy Research Working Paper No. 7071, October.

Benigno, G, C Huigang, C Otrok, A Rebucci and E Young (2011) "Monetary and macroprudential policies: an integrated analysis", $12^{\text {th }}$ Jacques Polak Annual Research Conference, International Monetary Fund, mimeo.

Bernanke, B.S. (2015) "Federal Reserve Policy in an International Context," Paper presented at $16^{\text {th }}$ Jaques Polak Annual Research Conference, November 5-6, 2015.

Bianchi, J (2011) "Overborrowing and systemic externalities in the business cycle", American Economic Review, vol. 101, no. 7, pp 3400-26.

BIS-FSB-IMF (2011) "Macroprudential policy tools and frameworks", Progress Report to G20.

Bussière, M, G Gaulier and W Steingress (2016) "Global trade flows: revisiting the exchange rate elasticities", Banque de France Working Papers, no. 608, Banque de France.

Calvo, G and C Reinhart (2002) "Fear of floating", Quarterly Journal of Economics, vol. 107, no. 2, pp 379-408.

Casas, C, F Diez, G Gopinath and P Gourinchas (2016) "Dominant currency paradigm", NBER Working Paper Series, no. 22943, December.

Cerutti, E, R Correa, E Fiorentino and E Segalla (2016) "Changes in prudential policy instruments: a new cross-country database", IMF Working Papers, no. 16, June.

Cheung, Y and X Qian (2009) "Empirics of China's outward direct investment", HKIMR Working Papers, no. 17, May.

Costinot, A, G Lorenzoni and I Werning (2014) "A theory of capital controls as dynamic termsof-trade manipulation", Journal of Political Economy, vol. 122, no. 1, pp 77-128.

Dooley, M, D Folkerts-Landau and P Garber (2003) "The revived Bretton Woods system", International Journal of Finance and Economics, vol. 9, no. 4, pp 307-13.

Dooley, M, D Folkerts-Landau and P Garber (2014) "The revived Bretton Woods system", NBER Working Paper Series, no. 20454, September.

Fernández, A, M Klein, A Rebucci, M Schindler and M Uribe (2015a) "Capital control measures: a new dataset", IMF Working Papers, no. 80, April.

Fernández, A, A Rebucci, M Schindler and M Uribe (2015b) "Are capital controls countercyclical?" Journal of Monetary Economics, vol. 76, pp 1-14.

Forbes, K, M Fratzscher and R Straub (2015) "Capital-flow management measures: what are they good for?" Journal of International Economics, vol. 96, no. S1, pp S76-S97. 
Forbes, K, M Fratzscher, T Kostka and R Straub (2016) "Bubble thy neighbour: portfolio effects and externalities from capital controls", Journal of International Economics, vol. 99, pp 85-104.

Fratzscher, M (2014) "Capital controls and foreign exchange policy" in: Fuentes, M, C Raddatz and C Reinhart (eds), Capital Mobility and Monetary Policy. Santiago, Chile: Central Bank of Chile.

G20 (2011) "G20 Coherent Conclusions for the Management of Capital Flows Drawing on Country Experiences", as endorsed by G20 Finance Ministers and Central Bank Governors, 15 October 2011.

Ghosh, A, J Ostry and C Tsangarides (2012) "Shifting motives: explaining the buildup in official reserves in emerging markets since the 1980s", IMF Working Papers, no. 34, January.

Hamilton, J and O Jorda (2002) "A model of the federal funds rate target", Journal of Political Economy, vol. 110, no. 5, pp 1135-67.

Heathcote, J and F Perri (2016) "On the desirability of capital controls," IMF Economic Review, vol. 64, no. 1, pp 75-102.

Hemrit, M (2013) "Pecking order macro-prudential tools: BOT's experience from tailored policy measures to Basel III's countercyclical buffer", Chapter 11, Basel III Implementation: Challenges and Opportunities, Kuala Lumpur: South East Asian Central Banks.

IDB (2016) "2016 Latin American and Caribbean macroeconomic report: Time to act: Latin America and the Caribbean facing strong challenges", Inter-American Development Bank, April.

Jeanne, O and A Korinek (2010) "Excessive volatility in capital flows: a Pigouvian taxation approach", American Economic Review, vol. 100, no. 2, pp 403-07.

Jeanne, O and R Ranciere (2006) "The optimal level of international reserves for emerging market countries: formulas and applications", IMF Working Papers, no. 229, October.

Jorda, O, M Schularick and A Taylor (2012) "When credit bites back: leverage, business cycles, and crises", Federal Reserve Bank of San Francisco Working Paper Series, no. 2011-27, October.

Korinek, A (2010) "Regulating capital flows to emerging markets: an externality view", (May). SSRN: https://ssrn.com/abstract=1330897 or http://dx.doi.org/10.2139/ssrn.1330897

Korinek, A (2011) "The new economics of prudential capital controls: a research agenda", IMF Economic Review, vol. 59, no. 3, pp 523-61.

Korinek, A (2016) "Currency wars or efficient spillovers? A general theory of international policy cooperation", NBER Working Papers, no. 23004, December.

Korinek, A and D Sandri (2016) "Capital controls or macroprudential regulation?" Journal of International Economics, vol. 99, no. S1, pp S27-S42.

Ljungqvist, L and T.J. Sargent (2004) Recursive Macroeconomic Theory, 2nd edition, Boston: MIT Press.

Mendoza, E (2002) "Credit, prices, and crashes: business cycles with a sudden stop", in: Edwards, $\mathrm{S}$ and J Frankel (eds), Preventing Currency Crises in Emerging Markets, Chicago: University of Chicago Press.

Monokroussoss, G (2011) "Dynamic limited dependent variable modelling and US monetary policy", Journal of Money, Credit and Banking, vol. 43, pp 519-34.

Ostry, J.D., M Chamon, A.R. Ghosh and M.S. Qureshi (2011) "Capital controls: when and why?" IMF Economic Review, vol. 59, no. 3, pp 562-80. 
Ostry, J.D., M Chamon, A.R. Ghosh and M.S. Qureshi (2012) "Tools for managing financialstability risks from capital inflows", Journal of International Economics, vol. 88, no. 2, pp 407-21.

Pasricha, G, M Falagiarda, M Bijsterbosch and J Aizenman (2015) "Domestic and multilateral effects of capital controls in emerging markets", NBER Working Paper Series, no. 20822, January.

Patel, N, Wang, Z and S Wei (2017) "Global value chains and effective exchange rates at the country-sector level", BIS Working Paper No. 637, May 2017.

Ramey, V (2016) "Macroeconomic shocks and their propagation", NBER Working Paper Series, no. 21978, February.

Riyanto, E (2016) "Unveiling macroprudential policy", Speech by Deputy Governor: $10^{\text {th }}$ International Conference on Bulletin of Monetary Economics and Banking, Bank Indonesia.

Schmitt-Grohé, S and M Uribe (2016) "Is optimal capital-control policy countercyclical in openeconomy models with collateral constraints?" NBER Working Paper Series, no. 22481, August.

Schularick, M and A M Taylor (2012) "Credit booms gone bust: monetary policy, leverage cycles, and financial crises, 1870-2008", American Economic Review, vol. 102, no. 2, 1029-61.

Shambaugh, J C (2004) "The effect of fixed exchange rates on monetary policy", Quarterly Journal of Economics, vol. 119, no. 1, pp 301-52.

Silva, P G (2016) "Chile's experience in macroprudential policy and institutional governance", Central Bank of Chile, mimeo.

Taylor, J (1993) "Discretion versus policy rules in practice", Carnegie-Rochester Conference Series on Public Policy, 39, pp 195-214.

Tinbergen, J (1962) Shaping the world economy: Suggestions for an international economic policy, New York: Twentieth Century Fund.

Uribe, M (2007) "On overborrowing", American Economic Review Papers and Proceedings, vol. 96, pp 417-21.

Weigel, A, M Liniger and C Appenzeller (2007) "The discrete brier and ranked probability skill scores". Federal Office of Meteorology and Climatology (MeteoSwiss). 


\section{Appendix}

Table A.1: Data Sources

\begin{tabular}{|c|c|c|}
\hline Data Sources & Description & Source \\
\hline $\begin{array}{l}\text { Spot Exchange Rate } \\
\text { against US dollar }\end{array}$ & $\begin{array}{l}\text { Weekly average of daily nominal spot exchange rate } \\
\text { against US dollar, expressed in local currency units (LCU) } \\
\text { per dollar. Year-over-year (yoy) changes computed as } \\
\text { log difference over previous } 52 \text { weeks. Quarter-over- } \\
\text { quarter (qoq) changes computed as log difference over } \\
\text { previous } 13 \text { weeks. Changes expressed as percentage } \\
\text { points. Also computed are deviations of the current } \\
\text { exchange rate from 3- and 5- and 10-year (156, } 260 \text { and } \\
520 \text { weeks respectively) backward-looking moving } \\
\text { averages. [For } 10 \text {-year trends, if the past } 10 \text {-year data } \\
\text { was not available to compute the trend, the trend was } \\
\text { computed with as much data as available, as long as at } \\
\text { least } 5 \text { years of past data was available. Otherwise, the } \\
\text { first } 5 \text { years of non-missing data was used to compute } \\
\text { the trend, in which case the trend is both backward- and } \\
\text { forward-looking for the first five years of observations.] }\end{array}$ & Datastream \\
\hline Real Effective & JP Morgan Broad Effective Exchange Rate Index, PPI & JP Morgan, via \\
\hline Exchange Rate (REER) & $\begin{array}{l}\text { based, } 2010=100 \text { (Haver codes: } X^{* * * P P H @ I N T D A I L Y) . ~} \\
\text { Weekly averages of daily data. Changes and deviations } \\
\text { from trend computed as for nominal exchange rates. }\end{array}$ & Haver \\
\hline Nominal Effective & Nominal Broad Effective Exchange Rate (Average, & BIS via Haver \\
\hline $\begin{array}{l}\text { Exchange Rate } \\
\text { (NEER) }\end{array}$ & $\begin{array}{l}2010=100) . \text { Weekly data linearly interpolated from } \\
\text { monthly. Changes and deviations from trend } \\
\text { computed as for nominal exchange rate against USD. }\end{array}$ & \\
\hline CPI Inflation (yoy \%) & $\begin{array}{l}\text { Year-over-year log difference of seasonally adjusted } \\
\text { CPI (2010-100). CPI data is available at quarterly } \\
\text { frequency and is first seasonally adjusted using Census } \\
\text { X12 method in E-views, and then linearly interpolated } \\
\text { to weekly frequency, before computing inflation rates } \\
\text { over the previous } 52 \text { weeks. }\end{array}$ & BIS and IMF IFS \\
\hline $\begin{array}{l}\text { Total Credit-To-GDP } \\
\text { Gap (\%) }\end{array}$ & $\begin{array}{l}\text { BIS Total Credit to GDP gap. Interpolated to weekly } \\
\text { from quarterly data. }\end{array}$ & BIS \\
\hline $\begin{array}{l}\text { Bank Credit-To-GDP } \\
\text { Gap (\%) }\end{array}$ & $\begin{array}{l}\text { Deviation of adjusted bank credit to the private non- } \\
\text { financial sector (market value, end of quarter, \% of } \\
\text { GDP) from its backward-looking HP-filtered trend } \\
\text { (lambda }=25000 \text { ). Bank credit gap computed at } \\
\text { quarterly frequency and then interpolated to weekly } \\
\text { frequency. }\end{array}$ & BIS \\
\hline External Credit Gap & $\begin{array}{l}\text { External credit gap is the deviation of external credit } \\
\text { (as percentage of GDP) from its lagged } 10 \text {-year moving } \\
\text { average. External credit is the sum of stock of liabilities } \\
\text { to BIS reporting banks (locational banking statistics) } \\
\text { and the outstanding stock of international debt } \\
\text { securities (from BIS International Debt Securities } \\
\text { Database). The external credit to GDP series is } \\
\text { interpolated from quarterly data. }\end{array}$ & BIS \\
\hline
\end{tabular}


Table A.1 (Contd.)

\begin{tabular}{|c|c|c|}
\hline Data Sources & Description & Source \\
\hline $\begin{array}{l}\text { Previous Policy } \\
\text { Action }\end{array}$ & $\begin{array}{l}\text { An indicator variable that takes the value }+1 \text { if the last } \\
\text { available policy action was a tightening and }-1 \text { if the } \\
\text { previous policy action was an easing. Policy actions } \\
\text { refer to net inflow tightening actions or net NKI } \\
\text { restricting actions, depending on the specification. }\end{array}$ & $\begin{array}{l}\text { Author's } \\
\text { calculations }\end{array}$ \\
\hline Fiscal Stance & $\begin{array}{l}\text { Takes the value }+1 \text { if the change in structural balance is } \\
\text { positive, }-1 \text { for a decline in structural balance and } 0 \\
\text { otherwise. The general government structural balance } \\
(\% \text { of GDP) is from IMF WEO and is linearly } \\
\text { interpolated from annual data. }\end{array}$ & $\begin{array}{l}\text { IMF World } \\
\text { Economic Outlook }\end{array}$ \\
\hline $\begin{array}{l}\text { Monetary Policy } \\
\text { Stance }\end{array}$ & $\begin{array}{l}\text { Takes the value }+1 \text { if the change in the policy rate is } \\
\text { positive, }-1 \text { for a decline in policy rate and } 0 \text { otherwise. } \\
\text { Policy rates are official policy rates, spliced with } \\
\text { interbank rates if needed to backward-extend the } \\
\text { series (full details available on request). }\end{array}$ & BIS \\
\hline Nominal GDP In USD & $\begin{array}{l}\text { Nominal gross domestic product at current prices \& } \\
\text { exchange rates (Seasonally adjusted by Haver, Haver } \\
\text { codes: } H^{* * * N G C D @ E M E R G E) . ~ Q u a r t e r l y ~ v a l u e s ~ l i n e a r l y ~} \\
\text { interpolated to weekly. }\end{array}$ & $\begin{array}{l}\text { National Sources } \\
\text { via Haver }\end{array}$ \\
\hline $\begin{array}{l}\text { Exchange Market } \\
\text { Pressure }\end{array}$ & $\begin{array}{l}\text { Sum of normalized percentage nominal appreciation } \\
\text { against USD and normalized percentage increase in } \\
\text { reserves (both measured over the previous } 13 \text { weeks). } \\
\text { Both exchange rate appreciation and growth in } \\
\text { reserves are normalized using their country-specific } \\
\text { mean and standard deviations. Growth in reserves is } \\
\text { calculated as the change in reserves from IMF BOPS } \\
\text { financial account detail, and divided by the one-week } \\
\text { lagged outstanding total reserves (excluding gold) } \\
\text { from IMF IIP. Both change in reserves and reserves } \\
\text { series are linearly interpolated from quarterly data. }\end{array}$ & $\begin{array}{l}\text { IMF BOPS and IIP } \\
\text { via Haver, and } \\
\text { Datastream }\end{array}$ \\
\hline $\begin{array}{l}\text { Relative GDP Growth } \\
\text { (yoy, \%) }\end{array}$ & $\begin{array}{l}\text { Real GDP growth in the EME less world real GDP } \\
\text { growth. Real GDP growth is (in general) yoy growth in } \\
\text { seasonally adjusted real GDP in national currency from } \\
\text { Haver, and world real GDP growth from IMF WEO. } \\
\text { Quarterly growth rates are linearly interpolated. }\end{array}$ & $\begin{array}{l}\text { Haver and IMF } \\
\text { WEO }\end{array}$ \\
\hline $\begin{array}{l}\text { Manufacturing IIP } \\
\text { Growth (yoy, \%) }\end{array}$ & $\begin{array}{l}\text { Year over year growth in seasonally adjusted Index of } \\
\text { Industrial Production (IIP) for manufacturing sector } \\
\text { (ISIC D). For China, total IP excluding construction (ISIC } \\
\text { C+D+E) is used. Monthly IIP values interpolated to } \\
\text { weekly before computing 52-week growth rates. }\end{array}$ & BIS \\
\hline $\begin{array}{l}\text { Relative } \\
\text { Manufacturing IIP } \\
\text { Growth }\end{array}$ & $\begin{array}{l}\text { Manufacturing IIP growth in the relevant country } \\
\text { (computed as above), less average manufacturing } \\
\text { growth in all other EMEs in sample. }\end{array}$ & BIS \\
\hline $\begin{array}{l}\text { Export Volume } \\
\text { Growth (yoy, \%) }\end{array}$ & $\begin{array}{l}\text { Year over year growth, \%, Export volume index (2000 = } \\
\text { 100). Growth rates calculated from interpolated values. }\end{array}$ & UN COMTRADE \\
\hline $\begin{array}{l}\text { Export Growth (yoy, } \\
\%)\end{array}$ & $\begin{array}{l}\text { Year over year growth, \%, Merchandise Exports, Billions } \\
\text { USD. }\end{array}$ & IMF DOTS \\
\hline
\end{tabular}


Table A.1 (Contd.)

\begin{tabular}{|c|c|c|}
\hline Data Sources & Description & Source \\
\hline Equity Prices & $\begin{array}{l}\text { Weekly average of main stock market index, } 23 \text { Jun } \\
2004=100 . \text { Year over year percentage change and } \\
\text { deviation from } 10 \text {-year trend calculated as for nominal } \\
\text { exchange rate against USD. }\end{array}$ & $\begin{array}{l}\text { Haver (INT Daily } \\
\text { database) }\end{array}$ \\
\hline External Credit/GDP & $\begin{array}{l}\text { Total external credit raised by domestic sectors via } \\
\text { foreign banks and issuance of international debt } \\
\text { securities, divided by nominal GDP in USD. Sum of } \\
\text { total cross-border loans from BIS reporting banks in } \\
\text { USD (all sectors, all currencies, creditor reporting) from } \\
\text { BIS locational banking statistics and the amounts } \\
\text { outstanding of international debt securities (all } \\
\text { maturities, all sectors, market reported, nominal value) } \\
\text { in USD from BIS International Debt Securities Statistics. } \\
\text { Both the debt and GDP are interpolated to weekly } \\
\text { values before computing their ratio. Year over year } \\
\text { growth rates and deviation from 10-year trend as } \\
\text { computed for nominal exchange rate against USD. }\end{array}$ & BIS \\
\hline $\begin{array}{l}\text { External Credit/GDP, } \\
\text { Non-Banks }\end{array}$ & Same as external credit/GDP, but for non-banks only. & BIS \\
\hline $\begin{array}{l}\text { External Debt } \\
\text { Securities Net Flow } \\
\text { (\% of GDP) }\end{array}$ & $\begin{array}{l}\text { Net flows of international debt securities (all maturities, } \\
\text { issuers and currencies, market reported, nominal value) } \\
\text { in USD. Linear interpolation to weekly from quarterly } \\
\text { data. Then divided by nominal GDP in USD. }\end{array}$ & $\begin{array}{l}\text { BIS International } \\
\text { Debt Securities } \\
\text { Statistics }\end{array}$ \\
\hline $\begin{array}{l}\text { Foreign Currency } \\
\text { Debt Securities Stock } \\
\text { (\% of GDP) }\end{array}$ & $\begin{array}{l}\text { Amounts outstanding of foreign currency international } \\
\text { debt securities (all maturities and issuers, market } \\
\text { reported, nominal value) in USD. Linear interpolation to } \\
\text { weekly from quarterly data. Then divided by nominal } \\
\text { GDP in USD. Deviation from 10-year trend computed } \\
\text { as for nominal spot exchange rate against USD. }\end{array}$ & $\begin{array}{l}\text { BIS International } \\
\text { Debt Securities } \\
\text { Statistics }\end{array}$ \\
\hline $\begin{array}{l}\text { Foreign Currency } \\
\text { Debt Securities, Net } \\
\text { Flows (\% of GDP) }\end{array}$ & $\begin{array}{l}\text { Net flows of foreign currency international debt } \\
\text { securities (all maturities and issuers, market reported, } \\
\text { nominal value) in USD. Linear interpolation to weekly } \\
\text { from quarterly data. Then divided by nominal GDP in } \\
\text { USD. }\end{array}$ & $\begin{array}{l}\text { BIS International } \\
\text { Debt Securities } \\
\text { Statistics }\end{array}$ \\
\hline $\begin{array}{l}\text { Other Investment } \\
\text { Inflows (Trend Dev.) }\end{array}$ & $\begin{array}{l}\text { Deviation from 10-year backward-looking moving } \\
\text { average of financial account, other investment inflows } \\
\text { (liabilities) expressed as percentage of nominal GDP in } \\
\text { USD. Other investment inflows were seasonally } \\
\text { adjusted using Census X12 method in E-views. }\end{array}$ & IMF BOPS \\
\hline $\begin{array}{l}\text { Global Bank Claims } \\
\text { (\% of GDP) }\end{array}$ & $\begin{array}{l}\text { International bank claims, claims on residents, ratio to } \\
\text { GDP, NSA. Quarterly data from BIS, linearly } \\
\text { interpolated. }\end{array}$ & BIS \\
\hline VIX & CBOE Market Volatility Index, VIX [SPVIX@DAILY]. & CBOE via Haver \\
\hline
\end{tabular}


Table A.1 (Contd.)

\begin{tabular}{|c|c|c|}
\hline Data Sources & Description & Source \\
\hline $\begin{array}{l}\text { Macroprudential } \\
\text { Governance } \\
\text { Dummy }\end{array}$ & $\begin{array}{l}\text { Time dummy, equals } 1 \text { on or after the date of } \\
\text { strengthening of macroprudential governance } \\
\text { frameworks, described in Table } 2 \text { in the paper. Where a } \\
\text { precise date was not available, it was assumed. Dates } \\
\text { are as follows: Brazil: } 30 \text { Aug 2010; Chile } 30 \text { Apr 2011; } \\
\text { China: } 1 \text { Jan 2009; India: } 1 \text { Jan } 2011 \text { (RBI started } \\
\text { including financial stability in its mandate from } 1 \text { Jan } \\
\text { 2004, but Financial Stability Development Council was } \\
\text { established later, in Dec 2010), Indonesia: } 22 \text { Nov } 2011 \\
\text { (FSSB was established in 2003, but Bank Indonesia } \\
\text { received a macroprudential mandate on } 22 \text { Nov 2011), } \\
\text { Korea: } 31 \text { Jul 2008, Malaysia: } 19 \text { Aug } 2009 \text {, Mexico: } 29 \\
\text { Jul 2010, Peru: } 31 \text { Dec 2009, Philippines: } 1 \text { Jun 2011, } \\
\text { Russia: } 31 \text { Dec 2010, South Africa: } 31 \text { Dec } 2008 \text {, } \\
\text { Thailand: } 31 \text { Dec 2008, Turkey: } 8 \text { Jun } 2011 \text {. }\end{array}$ & \\
\hline $\begin{array}{l}\text { Growth of } \\
\text { Residential Property } \\
\text { Prices } \\
(\text { YoY, \%) }\end{array}$ & $\begin{array}{l}\text { 52-week log difference, expressed as percentage, of } \\
\text { Residential Property Prices (Nominal, } 2010=100 \text { ). The } \\
\text { RPP index is interpolated from quarterly values. }\end{array}$ & BIS \\
\hline $\begin{array}{l}\text { Federal Funds } \\
\text { Shadow Rate }\end{array}$ & $\begin{array}{l}\text { United States: Federal Funds Shadow Short Rate Point } \\
\text { Estimates (AVG, \% p.a.). }\end{array}$ & Haver \\
\hline
\end{tabular}




\begin{tabular}{|c|c|c|c|c|c|c|c|c|c|c|c|}
\hline & \multicolumn{4}{|c|}{ Original Variables } & \multirow[b]{2}{*}{ Median } & \multirow[b]{2}{*}{ S.D. } & \multirow[b]{2}{*}{ Min } & \multicolumn{4}{|c|}{ Standardized variables } \\
\hline & $\mathrm{N}$ & Min & Max & Mean & & & & Max & Mean & Median & S.D. \\
\hline $\begin{array}{l}\text { Weighted Net Inflow } \\
\text { Tightenings (non-FDI) }\end{array}$ & 16224 & -3.0 & 1.7 & 0.0 & 0.0 & 0.1 & -27.8 & 27.8 & 0.0 & 0.0 & 1.0 \\
\hline $\begin{array}{l}\text { Weighted Net NKI Restrictions } \\
\text { (non-FDI) }\end{array}$ & 16224 & -2.3 & 1.7 & 0.0 & 0.0 & 0.1 & -27.9 & 24.1 & 0.0 & 0.0 & 1.0 \\
\hline \multicolumn{12}{|l|}{ Mercantilist Motivations } \\
\hline Exchange Market Pressure & 15562 & -6.6 & 5.1 & 0.2 & 0.2 & 1.3 & -4.5 & 3.6 & 0.1 & 0.2 & 1.0 \\
\hline Export Growth (yoy, \%) & 16224 & -72.2 & 72.4 & 8.5 & 10.6 & 18.8 & -3.3 & 3.1 & 0.5 & 0.6 & 1.0 \\
\hline $\begin{array}{l}\text { Export Volume Growth (yoy, } \\
\%)\end{array}$ & 9010 & -77.7 & 61.5 & 6.3 & 6.4 & 12.5 & -3.8 & 5.9 & 0.7 & 0.8 & 1.1 \\
\hline $\begin{array}{l}\text { Manufacturing IIP Growth } \\
\text { (yoy, \%) }\end{array}$ & 14656 & -25.3 & 35.9 & 4.2 & 4.4 & 7.4 & -3.5 & 4.9 & 0.7 & 0.7 & 1.2 \\
\hline $\begin{array}{l}\text { Mercantilism Proxy (Nominal, } \\
\text { 13-wk appr., \%) }\end{array}$ & 16224 & -277.6 & 167.2 & 0.1 & 2.1 & 36.6 & -4.2 & 4.1 & 0.1 & 0.1 & 1.0 \\
\hline $\begin{array}{l}\text { Mercantilism Proxy (Nominal, } \\
\text { yoy appr., \%) }\end{array}$ & 16224 & -142.1 & 95.5 & 0.1 & 2.1 & 19.3 & -4.0 & 3.5 & 0.1 & 0.1 & 1.0 \\
\hline $\begin{array}{l}\text { Mercantilism Proxy (Real, 13- } \\
\text { wk appr., \%) }\end{array}$ & 16224 & -265.3 & 192.5 & -0.6 & 0.6 & 37.1 & -4.1 & 3.7 & 0.0 & 0.0 & 1.0 \\
\hline $\begin{array}{l}\text { Mercantilism Proxy (Real, yoy } \\
\text { appr., \%) }\end{array}$ & 16224 & -128.1 & 97.4 & -0.5 & -0.2 & 18.7 & -3.6 & 3.4 & 0.0 & 0.0 & 1.0 \\
\hline $\begin{array}{l}\text { Net Capital Inflows/GDP } \\
\text { (Deviation from 10-yr Trend) }\end{array}$ & 15576 & -16.2 & 10.8 & -0.1 & 0.1 & 3.2 & -3.2 & 3.6 & 0.0 & 0.0 & 1.0 \\
\hline $\begin{array}{l}\text { NEER (Deviation from 3-year } \\
\text { trend) }\end{array}$ & 14664 & -89.6 & 24.3 & -3.1 & -1.3 & 11.1 & -4.5 & 2.9 & -0.2 & -0.2 & 1.1 \\
\hline $\begin{array}{l}\text { NEER (Deviation from 5-year } \\
\text { trend) }\end{array}$ & 14664 & -132.5 & 28.0 & -6.0 & -2.6 & 16.8 & -4.7 & 3.0 & -0.3 & -0.3 & 1.2 \\
\hline NEER (qoq growth, \%) & 14664 & -33.5 & 18.4 & -0.4 & 0.0 & 4.8 & -4.6 & 3.5 & 0.0 & 0.0 & 1.0 \\
\hline NEER (yoy growth, \%) & 14664 & -56.5 & 34.5 & -1.5 & -0.9 & 9.6 & -4.0 & 3.3 & -0.1 & -0.1 & 1.0 \\
\hline Private Net Capital & & & & & & & & & & & \\
\hline $\begin{array}{l}\text { Inflows/GDP (Deviation from } \\
\text { 10-yr Trend) }\end{array}$ & 15576 & -16.5 & 11.8 & -0.1 & 0.0 & 3.3 & -3.3 & 3.5 & 0.0 & 0.0 & 1.1 \\
\hline $\begin{array}{l}\text { REER (Deviation from 3-year } \\
\text { trend) }\end{array}$ & 16224 & -38.7 & 27.5 & 0.9 & 0.9 & 7.7 & -4.0 & 3.7 & 0.1 & 0.1 & 1.0 \\
\hline $\begin{array}{l}\text { REER (Deviation from 5-year } \\
\text { trend) }\end{array}$ & 16224 & -35.5 & 33.7 & 1.5 & 1.4 & 9.7 & -3.7 & 3.4 & 0.2 & 0.2 & 1.1 \\
\hline REER (qoq growth, \%) & 16224 & -28.7 & 28.1 & 0.2 & 0.2 & 4.4 & -4.1 & 4.3 & 0.0 & 0.1 & 1.0 \\
\hline REER (yoy growth, \%) & 16224 & -32.8 & 34.9 & 0.8 & 0.6 & 8.2 & -3.5 & 3.4 & 0.1 & 0.1 & 1.0 \\
\hline Relative GDP Growth (yoy, \%) & 16224 & -13.6 & 11.6 & 0.5 & 0.4 & 3.0 & -4.2 & 6.3 & 0.3 & 0.2 & 1.3 \\
\hline $\begin{array}{l}\text { Relative Manufacturing IIP } \\
\text { Growth }\end{array}$ & 14656 & -19.9 & 32.4 & 0.0 & -0.1 & 5.9 & -3.5 & 5.2 & 0.0 & 0.0 & 1.2 \\
\hline $\begin{array}{l}\text { Spot Exchange Rate } \\
\text { (Deviation from 3-year trend) }\end{array}$ & 16217 & -97.1 & 78.9 & -1.8 & 0.0 & 13.8 & -3.8 & 5.1 & -0.1 & 0.0 & 1.1 \\
\hline $\begin{array}{l}\text { Spot Exchange Rate } \\
\text { (Deviation from 5-year trend) }\end{array}$ & 16217 & -146.8 & 150.6 & -3.2 & -0.1 & 22.4 & -3.9 & 3.8 & -0.1 & 0.0 & 1.1 \\
\hline $\begin{array}{l}\text { Spot Exchange Rate Against } \\
\text { US dollar (qoq growth, \%) }\end{array}$ & 16210 & -33.6 & 21.4 & -0.2 & 0.1 & 5.6 & -4.3 & 5.6 & 0.0 & 0.0 & 1.0 \\
\hline $\begin{array}{l}\text { Spot Exchange Rate Against } \\
\text { US dollar (yoy growth, \%) }\end{array}$ & 16217 & -55.9 & 45.8 & -0.6 & 0.0 & 11.9 & -3.6 & 3.6 & 0.0 & 0.0 & 1.0 \\
\hline
\end{tabular}


Table A2 (contd.): Summary Statistics

\begin{tabular}{|c|c|c|c|c|c|c|c|c|c|c|c|}
\hline & \multicolumn{5}{|c|}{ Original Variables } & \multicolumn{6}{|c|}{ Standardized variables } \\
\hline & $\mathrm{N}$ & Min & Max & Mean & Median & SD & Min & Max & Mean & Median & SD \\
\hline \multicolumn{12}{|c|}{ Macroprudential Motivations } \\
\hline $\begin{array}{l}\text { Bank Credit to Private } \\
\text { non-Financial Sector } \\
\text { (\% of GDP), qoq change }\end{array}$ & 14664 & -6.5 & 10.5 & 0.3 & 0.3 & 1.2 & -4.8 & 4.5 & 0.4 & 0.4 & 1.0 \\
\hline $\begin{array}{l}\text { Bank Credit to Private } \\
\text { non-Financial Sector } \\
\text { (\% of GDP), yoy change }\end{array}$ & 14664 & -21.6 & 22.7 & 1.2 & 1.2 & 3.9 & -3.4 & 3.9 & 0.5 & 0.5 & 1.1 \\
\hline $\begin{array}{l}\text { Bank Credit to Private } \\
\text { non-Financial Sector } \\
\text { (qoq \% growth) }\end{array}$ & 14664 & -12.8 & 17.6 & 3.4 & 3.1 & 3.1 & -3.9 & 5.6 & 1.4 & 1.3 & 1.1 \\
\hline $\begin{array}{l}\text { Bank Credit to Private } \\
\text { non-Financial Sector } \\
\text { (yoy \% growth) }\end{array}$ & 14664 & -25.2 & 67.2 & 14.8 & 13.4 & 12.1 & -2.1 & 5.5 & 1.8 & 1.7 & 1.2 \\
\hline $\begin{array}{l}\text { Bank Credit-to-GDP } \\
\text { gap (\%) }\end{array}$ & 14664 & -23.5 & 16.9 & 1.4 & 2.0 & 5.4 & -2.6 & 4.0 & 0.4 & 0.6 & 1.1 \\
\hline $\begin{array}{l}\text { Equity Prices } \\
\text { (yoy growth, \%) }\end{array}$ & 15801 & -133.0 & 137.6 & 9.4 & 9.2 & 29.7 & -3.1 & 3.4 & 0.4 & 0.4 & 1.0 \\
\hline $\begin{array}{l}\text { Equity Prices, (23 Jun } \\
2004=100 \text { ) Trend } \\
\text { Deviation }\end{array}$ & 15935 & -187.9 & 849.8 & 80.2 & 57.1 & 105.5 & -1.3 & 4.4 & 1.0 & 0.9 & 1.1 \\
\hline $\begin{array}{l}\text { External Credit (\% of } \\
\text { GDP) }\end{array}$ & 16186 & 2.5 & 76.2 & 18.2 & 16.3 & 9.5 & 0.3 & 8.6 & 4.0 & 3.9 & 1.6 \\
\hline $\begin{array}{l}\text { External Credit } \\
\text { (\% of GDP), yoy change }\end{array}$ & 16134 & -38.9 & 20.1 & -0.1 & 0.1 & 3.5 & -3.1 & 3.6 & 0.1 & 0.0 & 1.0 \\
\hline $\begin{array}{l}\text { External Credit (\% of } \\
\text { GDP), Trend Deviation }\end{array}$ & 16186 & -31.0 & 41.1 & -0.9 & -0.2 & 7.3 & -2.6 & 3.7 & 0.0 & -0.1 & 1.2 \\
\hline $\begin{array}{l}\text { External Credit by non- } \\
\text { Banks ( } \% \text { of GDP) }\end{array}$ & 16186 & 0.9 & 71.8 & 13.0 & 11.2 & 8.5 & 0.3 & 9.4 & 3.8 & 3.7 & 1.7 \\
\hline $\begin{array}{l}\text { External Credit by non- } \\
\text { Banks (\% of GDP), } \\
\text { yoy change }\end{array}$ & 16134 & -33.1 & 12.1 & -0.2 & 0.0 & 2.8 & -2.7 & 3.3 & 0.0 & 0.0 & 1.0 \\
\hline $\begin{array}{l}\text { External Debt Securities } \\
\text { Net Flow (\% of GDP) }\end{array}$ & 16186 & -43.5 & 9.2 & 0.8 & 0.6 & 2.2 & -6.6 & 4.8 & 0.6 & 0.4 & 1.0 \\
\hline $\begin{array}{l}\text { External Debt Securities } \\
\text { Stock (\% of GDP) } \\
\text { External Debt Securities }\end{array}$ & 16186 & 0.3 & 62.8 & 10.1 & 9.0 & 7.2 & 0.2 & 9.7 & 3.4 & 3.4 & 1.8 \\
\hline $\begin{array}{l}\text { Stock (\% of GDP), } \\
\text { yoy change }\end{array}$ & 16134 & -26.5 & 6.4 & 0.1 & 0.1 & 2.4 & -2.9 & 3.6 & 0.2 & 0.1 & 1.0 \\
\hline $\begin{array}{l}\text { Foreign Currency Ext. } \\
\text { Debt Securities Net } \\
\text { Flow (\% of GDP) } \\
\text { Foreign Currency Ext. }\end{array}$ & 16186 & -43.3 & 9.2 & 0.8 & 0.5 & 2.1 & -6.6 & 4.9 & 0.6 & 0.4 & 1.0 \\
\hline $\begin{array}{l}\text { Debt Securities Stock } \\
\text { (\% of GDP) }\end{array}$ & 16186 & 0.3 & 62.3 & 9.5 & 8.2 & 7.1 & 0.2 & 9.0 & 3.3 & 3.3 & 1.7 \\
\hline $\begin{array}{l}\text { Foreign Currency Ext. } \\
\text { Debt Securities Stock } \\
\text { (\% of GDP), yoy change }\end{array}$ & 16134 & -26.3 & 6.5 & 0.1 & 0.1 & 2.3 & -2.9 & 3.5 & 0.2 & 0.1 & 1.0 \\
\hline $\begin{array}{l}\text { Foreign Currency Ext. } \\
\text { Debt Securities Stock } \\
\text { (\% of GDP, Trend } \\
\text { Deviation) }\end{array}$ & 16186 & -24.0 & 35.5 & 0.2 & 0.3 & 4.8 & -2.4 & 3.8 & 0.3 & 0.2 & 1.2 \\
\hline $\begin{array}{l}\text { Residential Property } \\
\text { Prices (yoy growth, \%) }\end{array}$ & 10362 & -24.1 & 49.5 & 6.6 & 5.3 & 8.1 & -2.5 & 7.2 & 1.5 & 1.3 & 1.5 \\
\hline $\begin{array}{l}\text { Short Term Ext. Debt } \\
\text { Securities Net Flow } \\
\text { (\% of GDP) }\end{array}$ & 14664 & -1.8 & 2.5 & 0.0 & 0.0 & 0.2 & -5.7 & 5.9 & 0.1 & 0.0 & 0.9 \\
\hline $\begin{array}{l}\text { Total Credit-to-GDP } \\
\text { Gap (\%) }\end{array}$ & 11691 & -51.0 & 39.9 & -0.2 & 2.2 & 13.3 & -2.8 & 3.4 & 0.2 & 0.3 & 1.3 \\
\hline
\end{tabular}

